\title{
Os visitantes do Museu Paulista: um estudo comparativo com os visitantes da Pinacoteca do Estado e do Museu de Zoologia
}

RESUMO: Neste artigo pretende-se discutir as diferenças entre os públicos de museus de história, arte e ciência, com um aprofundamento nas motivações e expectativas dos visitantes. Para o Museu Paulista apresentarei de forma detalhada a "fala" dos visitantes em relação aos benefícios da visita e ao que mais gostaram, dando uma leitura preliminar de seu conteúdo.Dessa maneira, pensa-se em colaborar para o desenvolvimento dos estudos de públicos no Brasil, ainda pouco sistemáticos, mas que permitem aos museus conhecer seus públicos e assim criar e aperfeiçoar seus programas, de acordo com sua missão, mas com uma visão mais clara dos seus interlocutores/visitantes e até de seus "não-visitantes". Inicialmente, discutirei a questão da tipologia dos museus, por ser a base da hipótese de pesquisa, ou seja, se o perfil, as motivações e expectativas dos públicos variam conforme o tipo de museu. Em seguida, apresentarei referenciais teóricos e estudos que nortearam a metodologia e alguns dos resultados obtidos. $\mathrm{Na}$ última parte, descreverei as respostas dos visitantes do Museu Paulista às questões abertas, procurando identificar as leituras das exposições apresentadas, na visão do receptor/visitante. Este trabalho abriu um conjunto de questões para novas investigações sobre as condições dos visitantes e suas leituras das exposições.

PALAVRAS-CHAVE: Museu de história. Público de museus. Comunicação em museus.

ABSTRACT: This article presents and discusses the differences between the audiences of history, science and art museums, with emphasis on visitors' motivations and expectations. The "discourse" of Museu Paulista visitors will be described in terms of what they liked most and what benefits they felt they have gained with the visit. The article intends to contribute to Brazilian studies on museums' audiences, an area that is still evolving. Audience surveys may 
2. Uma parte das idéias apresentada neste artigo foi também discutida em Almeida e Lopes (2004).

3. Os dados foram coletados no período de uma semana, entre janeiro e fevereiro de 2003, por meio de questionários preenchidos pelos visitantes acima de 15 anos à saída dos museus. $\mathrm{O}$ questionário continha 17 questões, sendo 14 fechadas de perfil demográfico e de hábitos culturais e três abertas sobre os be nefícios da visita, apreciação e sugestões. No total validei 169 questionários de visitantes do Museu de Zoologia, 466 do Museu Paulista e 1.239 da Pinacoteca.

4. Cristina Silva (1989) fez, no Brasil, o único estudo comparativo que engloba públicos de diferentes tipos de museus. Comparando o número de visitantes de museus brasileiros a partir de dados de estatísticas oficiais do Instituto Brasileiro de Geografia e Estatística evidenciou uma tendência a maior visitação em zoológicos e museus de história natural do que em museus de história e de artes. Para a autora, número de visitantes dependia mais da localização do museu - estar em um parque ou área aberta, fazer parte de atração turística - e do fato de ficar aberto aos fins de semana e feriados, do que de sua tipologia/coleção propriamente dita.

Apesar de ter sido feita na década de 1980, a classificação de Silva (1989) para museus de alta visitação (mais de 50.000 visitantes/ano), média (de 5.001 a 50.000 visitantes/ano) baixa (menos de $5.000 \mathrm{vi}$ sitantes/ano) nos parece ainda atual, mesmo sem help museums to reorganize their programmes according to their mission, but with a clear view of the interests of their present and potential audiences. Initially, this article debates the issue of the museums' typology as the basis for the research hypothesis: whether the visitors' motivations and expectations vary according to museum type. Then, the theoretical references guiding the methodology will be presented, as well as some empirical results. In the last part, the responses of Museu Paulista visitors are described, presenting their interpretation of the museum's exhibitions, from the receiver/audience's point of view. This paper has brought forth many issues for further investigation on museum attendance and visitor's interpretation of exhibitions.

KEYWORDS: History Museums. Museum Audience. Communication in Museums.

Neste artigo ${ }^{2}$ pretende-se discutir o perfil dos visitantes do Museu Paulista, um museu de história, em comparação com aquele da Pinacoteca do Estado, um museu de arte, e do Museu de Zoologia/USP, um museu de ciência, aprofundando-se nas motivações e expectativas dos visitantes, a partir de pesquisas de públicos. Trata-se de uma primeira análise e divulgação de resultados em revista nacional. Apresentarei, ainda, de forma detalhada a "fala" dos visitantes do Museu Paulista em relação ao que consideraram como benefícios da visita, preferências e do que sentiram falta, buscando compreender melhor a experiência vivida no museu. Este trabalho abriu um conjunto de questões para novas investigações sobre as condições dos visitantes e suas leituras das exposições.

Dessa maneira, pretende-se colaborar com o desenvolvimento dos estudos de públicos no Brasil, ainda pouco sistemáticos, que permitem aos museus conhecer seus públicos e assim criar e aperfeiçoar seus programas, de acordo com sua missão e com uma visão mais clara dos seus interlocutores/visitantes e até de seus "não-visitantes".

Partindo da hipótese de que o perfil, as motivações e expectativas dos públicos variam conforme a tipologia do museu, discutirei a questão da tipologia. Em seguida apresentarei referenciais teóricos e estudos que nortearam minha metodologia e alguns dos resultados obtidos.

Na última parte, descreverei as respostas dos visitantes do Museu Paulista às questões abertas, procurando identificar algumas das leituras das exposições apresentadas na visão do receptor/visitante.

Tipologia dos museus: as diferenças entre museus de história, arte e ciência do ponto de vista dos profissionais de museus e dos seus visitantes

Uma das questões iniciais de minha pesquisa é a possível diferença entre os públicos de museus de história, ciência e arte no Brasil e em outros países. Com o propósito de conhecer os diferentes públicos de um museu de arte, Pinacoteca do Estado; de um museu de história, Museu Paulista/USP; e de 
um museu de ciências biológicas, Museu de Zoologia/USP, da cidade de São Paulo; e analisar o perfil socioeconômico, os hábitos culturais, as motivações e as expectativas desse público em relação à visita, realizei um estudo exploratório por meio de questionários respondidos pelos visitantes ${ }^{3}$.

Os três museus são centenários, recebem um número de visitantes grande comparando-se com outros museus da cidade ou mesmo do país e têm prédios de destaque, cercados por um parque. Os três mantêm exposições de longa duração de seus acervos e ficam abertos ao público sábados e domingos ${ }^{4}$.

Fundada pelo governo do Estado de São Paulo, em 1905, a Pinacoteca do Estado, localizada na área central da cidade, com acesso fácil por metrô, trem ou ônibus, teve seu público ampliado nos últimos oito anos, depois de uma ampla reforma de seu prédio e da realização de exposições "arrasa quarteirões" como a de Rodin, em 1995. Seu acervo, com cerca de seis mil obras, é composto por pinturas, esculturas, desenhos, gravuras, fotografias e objetos de artistas brasileiros e estrangeiros, do século XIX até a atualidades. $\bigcirc$ prédio, construído em 1900 para abrigar o Liceu de Artes e Ofícios, foi também ocupado pela Escola de Belas Artes e só recentemente passou a ser usado com exclusividade pela Pinacoteca. A reforma realizada na década de 1990 modernizou algumas instalações e fez do prédio uma atração para interessados em Arquitetura. Ao lado do prédio, fica o Parque da Luz, com ampla área verde e um conjunto de esculturas também pertencente à Pinacoteca. No ano de 2002, ela recebeu cerca de 175.000 visitantes $^{\circ}$.

Museu Paulista da Universidade de São Paulo, fundado em 1893 como um museu de história natural, é desde a década de 1930 um museu de história do Brasil, com destaque para o Estado de São Paulo7. Seu acervo reúne objetos como utensílios domésticos, indumentária, armaria, veículos, que entre outros somam mais de 30.000 peças; iconografia como pinturas, fotografias, postais, gravuras completam cerca de 50.000 peças; além da documentação arquivística e coleções textuais. Costuma apresentar pequenas exposições temporárias. Localiza-se no bairro do lpiranga, onde teria sido declarada a Independência do Brasil, em 1822. Seu prédio, construído entre 1885 e 1890, para ser um monumento à Independência do Brasil, é uma referência histórica e turística para a cidade, constituindo-se em elemento de atração para muitos visitantes. O Museu Paulista fica no Parque da Independência, com outros monumentos referentes a esse evento e ampla área verde. Recebe mais de 250.000 mil visitantes por ano ${ }^{8}$.

Instalado em prédio no bairro do Ipiranga, próximo ao Museu Paulista, - Museu de Zoologia se destaca como um centro de pesquisas e depositário de coleções zoológicas, com cerca de oito milhões de exemplares de espécies animais, sendo referência para a pesquisa sobre a fauna neotropical' ${ }^{9}$ Sua exposição de longa duração foi totalmente reformulada em 2002: a exposição organizada por grupos zoológicos cedeu lugar a uma outra sobre a pesquisa científica em Zoologia, seus processos e resultados. Na versão anterior da exposição, o Museu de Zoologia recebia cerca de 70.000 visitantes por ano ${ }^{10}$ novos levantamentos para confirmá-la.

5. Algumas telas da Pinacoteca faziam parte de coleções do Museu Paulista e foram transferidas em 1904 e posteriormente. $\mathrm{O}$ critério para a transferência baseava-se na idéia de que no Museu Paulista só deveriam ficar as telas que teriam "temas históricos" (MENESES, 1992a).

6. Dado fornecido pela Área Educativa da Pinacoteca do Estado.

7. Embora possua acervo abarcando peças desde o fim do século XVII, o Museu Paulista coloca como prioritário o período de 1850 a 1950 para aquisição de acervo e pesquisa. Essa proposta foi explicitada por Ulpiano Bezerra de Meneses durante sua gestão como diretor, além das três linhas de pesquisa:"cotidiano e sociedade", "universo do trabalho"e "história do imaginário" (MENESES, 1992b, p. 7-10)

8. Dado obtido em Anuário estatístico da USP acessado por Internet <http://www.usp.br> em 1/12/2003. Entre 1999 e 2002, a visitação aumentou de 240.612 para 285.314 visitantes.

9. O Museu de Zoologia da Universidade de São Paulo é um museu biológico cujas coleções fizeram parte do Museu Paulista (desde 1894), depois foram transferidas para a Secretaria de Agricultura para compor o Departamento de Zoologia e somente em 1969 iriam constituir o Museu de Zoologia, ao serem passadas para a Universidade de São Paulo.

10.SANTOS, 1998.Segundo o Anuário estatístico, em 1999 a visitação foi de 
15.332 pessoas. Em 2000 e 2001, o museu ficou fechado para reforma.

11. Dado fornecido pelo Serviço de Museologia do Museu de Zoologia em novembro de 2003

12. O número de estudos de público em museus de história é bem menor do que os de museus de ciência e de arte, pelo que pude verificar até o momento.

13. Algumas pesquisas comparativas entre públicos de diferentes tipos de museus na bibliografia internacional indicam que os visitantes de museus são mais escolarizados e têm maior renda do que a média da população, que os visitantes de museus de arte preferem vi sitá-los sozinhos ou com menos acompanhantes do que nos museus de ciências e que geralmente há mais crianças em museus de ciências do que nos de arte (LINTON et al., 1992; LEHALLE; MI RONER, 1993; DOERING BICKFORD, 1997; DIGBY 1973)

14. Falk e Dierking, por exemplo, citam a pesquisa do antropólogo Nelson Grabun que afirma que algumas pessoas buscam uma experiência reverencial no museu,"a persona experience with something higher,more sacred, and out of the ordinary than home and work are able to supply." Assim, o museu proporcionaria um espaço diferente do cotidiano (FALK; DIERKING, 1992, p. 15)

15. FREIRE, 1993. e no primeiro ano da nova (setembro de 2002 a setembro de 2003) recebeu mais de 59.000 visitantes".

As atuais diferenças entre museus de arte, história e ciência têm raízes na moderna compartimentalização das disciplinas, que passaram a exigir "olhares" distintos. Anteriormente, os museus eram ecléticos, assim como os cientistas/artistas renascentistas que desenvolviam estudos em diversos campos do conhecimento. Ainda no século XIX, os grandes museus de história natural apresentavam exposições de Ciências Naturais, Exatas, Antropologia, Arqueologia e eventualmente Arte. Durante o século XX, a maior parte deles foi fragmentada em diferentes museus e centros de pesquisa: Zoologia, Botânica, Geologia, Arqueologia, Antropologia, entre outros.

Esse processo de fragmentação ocorreu com o acervo do Museu Paulista: as coleções zoológicas formaram o núcleo inicial do que seria mais tarde o Museu de Zoologia; parte de suas coleções de arte foi para o acervo da Pinacoteca do Estado; e mais tarde, na década de 1990, suas coleções de Arqueologia e Etnologia foram transferidas para o Museu de Arqueologia e Etnologia da Universidade de São Paulo.

Esses diferentes tipos de museus parecem atrair vários tipos de públicos, sugerindo formas diversas de "olhar" e incitar diferentes abordagens de pesquisa.

Nas pesquisas de público aparecem algumas diferenças de abordagens de acordo com a tipologia do museu. Quando iniciei minha investigação sobre avaliação em museus, há mais de 12 anos, encontrei extensa bibliografia sobre experiências de avaliação em museus de ciência e de arte ${ }^{12}$. Entre os trabalhos realizados em museus de ciência - aqui incluídos os das áreas de biológicas e exatas - e nos centros de ciências, percebi uma grande quantidade de estudos relacionados à aprendizagem. Já no caso dos museus de arte, especificamente de artes visuais, as pesquisas procuravam conhecer o gosto e a percepção das obras pelos visitantes, sendo um exemplo clássico o estudo de Bourdieu e Darbel em museus de arte europeus (BOURDIEU; DARBEL, $2003)^{13}$.

As diferenças entre museus de arte, história e ciência podem ser analisadas por vários ângulos. Elas certamente também têm raízes na concepção do que seria Arte, História e Ciência, quem deve praticá-las, para que servem, para quem são feitas. Duncan Cameron, museólogo cujo pensamento é referência na área de comunicação em museus, ao discorrer sobre as origens dos museus, considerou que os de ciência "since the time of the Wunderkammern with their ostrich eggs, coconuts, nautilus shells and crystals, have been offering the public science education", mesmo que o público ali busque e encontre a mágica e a alquimia. Já os museus de arte "in both classical and modern times have offered an aesthetic experience, and in the centuries in between art has offered a religious experience" (CAMERON, 1995, p. 50). Encarar a visita ao museu de arte como uma busca ao "sagrado" aparece em outras pesquisas fora do Brasil|' e de maneira indireta aqui também ${ }^{15}$, mas a concepção do museu, de qualquer tipologia, como um espaço educacional, aparece de maneira muito mais clara em nossos resultados. 
A visita a um museu com fins pedagógicos, na nossa pesquisa, é a resposta mais freqüente para dois museus: aparece nos discursos de $61 \%$ dos visitantes que foram ao Museu de Zoologia (MZ) e em $48 \%$ dos que foram ao Museu Paulista (MP). No caso da Pinacoteca (Pina) há uma pequena diferença entre os benefícios culturais (30\%) e educacionais (29\%). Ou seja, não é somente o museu de ciência que é visto principalmente como um espaço educacional, mas todos os tipos de museus. Na Pinacoteca apenas $8 \%$ afirmaram ter tido uma experiência contemplativa, de prazer de olhar o belo, freqüência muito semelhante aos 5\% dos visitantes do Museu de Zoologia ${ }^{16}$. Pode-se afirmar que apenas de forma parcial os resultados confirmam as colocações de Cameron, ou seja, o público dos museus pesquisados dá grande valor ao aspecto educacional dos museus, independentemente de sua tipologia, o que sugere pensar em um entendimento mais amplo de educação que não se restringe ao pedagógico especificamente. Essa questão ainda será retomada mais adiante.

Para alguns autores como Fath Davis Ruffins, historiador do National Museum of American History (Smithsonian Institution), as diferenças entre as exposições de arte e história se dariam a partir da origem dos objetos: pintura, escultura, fotografia e outras expressões artísticas seriam fruto de ação consciente para criação de uma proposta estética:

In that sense, art objects are meant to speak directly to the viewer. Art museums often define their role as the development of connoisseurship, the informed appreciation of the art object for its intrinsic excellence or quality. Art museums exhibitions are thus designed to encourage the act of looking (RUFFINS, 1986, p. 27).

Já os objetos históricos, de uso cotidiano, raras vezes são produzidos explicitamente para comunicar e no geral sua apreciação estética é secundária.

Historical artifacts were not made to speak directly; only the antiquarian, curator, or historian with prior knowledge is likely to 'hear' their cryptic messages. The creation of the most effective context for understanding is therefore the chief objective in developing a history exhibition (RUFFINS, 1986, p. 27).

Semelhanças entre museus de história e de ciência seriam dadas por ambos terem orientação temática (subject-matter orientation): pretendem ensinar pela perspectiva de cada disciplina e os conteúdos de cada uma delas. Entretanto, Ruffins afirma que Ciência e História têm diferentes padrões de "evidence and proof". Os cientistas buscam leis naturais, estudam o mundo material e suas relações abstratas. Grande parte deles acredita estar buscando verdades básicas ("basic truths") que poderiam ser demonstradas experimentalmente, negando os aspectos políticos e culturais da pesquisa científica. Os historiadores estudam as sociedades e eventos do passado, o que não pode ser demonstrado experimentalmente.

By definition, history is the analysis and interpretation of something which was only "true" once, in the past. Evidence and proof must be based not on replicability but rather on a carefully argued synthesis of a wide variety of period source materials. History can be viewed
16. Entre os respondentes do Museu Paulista, apenas $1 \%$ indicou como benefício "ver coisas belas/novas". 
as a search for truth, but the outcome is never truth, only argument, always interpretation (Ruffins, 1986, p. 27-28).

Para o autor, a ciência apresenta-se totalmente desvinculada de seus aspectos históricos, e a arte é vista de forma descolada do cotidiano, o que em muitas sociedades não-ocidentais não ocorre e mesmo na sociedade ocidental atual. Além disso, conceber a diferença de tipologia dos museus unicamente a partir de seus objetos não é produtivo, pois há muitas obras de arte em museus de história, documentos históricos em museus de ciências e de arte, etc.

Concordo com Ulpiano Bezerra de Meneses quando afirma que um museu se define mais por sua perspectiva de pesquisa do que pelo seu acervo:

[...] concebe-se correntemente o museu histórico como aquele que opera com objetos históricos. $\mathrm{Se}$, contudo, é a dimensão do conhecimento que sobe à tona, é preciso retificar e dizer, como vimos, que o museu histórico deve operar com problemas históricos, isto é, problemas que dizem respeito à dinâmica na vida das sociedades (MENESES, 1994a, p. 20).

Meneses ressalta que sempre houve uma relação ambígua entre museus de arte e museus de história:

Assim, por exemplo, na Inglaterra vitoriana e, mais ainda, nos Estados Unidos, os fundadores de museus exploraram a estética, nos museus históricos e antropológicos, para industriar e formar disciplinarmente o povo em geral e as classes operárias em particular e, num segundo momento, para reafirmar - nos EUA - valores americanos como contraponto aos riscos da imigração e, em seguida, estímulo ao progresso. Quanto aos museus antropológicos, sempre foram acusados de se apropriarem ideologicamente de "outras culturas", estetizando-as. E os museus de "artes decorativas" muitas vezes constituíram um modelo variante de museu histórico (MENESES, 1994a, p. 16).

Mais adiante o autor explica que é impossível "o desfrute estético em estado puro" mesmo em museus de arte, pois "não há como assegurar tal recolhimento contemplativo absoluto" e continua:

A história dos museus de arte revela a rejeição de tal partido, de sorte que todo museu da espécie (incluindo de arte contemporânea, aqueles mesmos que Argan opunha ao caráter "patrimonialista" dos museus de "arte antiga") é, em última análise, um museu de história da arte. Ainda que não haja conceito explícito, um conceito implícito sempre estará presente como princípio organizativo (MENESES, 1994a, p. 25).

Tomando a Pinacoteca do Estado como exemplo, pode-se concordar com a colocação de Meneses, uma vez que a organização de seu acervo se dá por movimentos artísticos cronologicamente definidos. Mais ainda, a exposição temporária sobre Albert Eckhout, que estava em exibição no período que realizei a pesquisa de campo, apresentava uma abordagem histórica, contextualizando a produção, exibição e conteúdo das obras. Essa característica refletiu-se no discurso dos visitantes, que citaram repetidamente os aspectos históricos da mostra, ao responderem sobre "os benefícios da visita". As palavras "história/histórico" foram citadas 132 vezes (12,5\% dos 1.054 que responderam 
à pergunta) pelos visitantes da Pinacoteca, enquanto "arte" foi citada 144 vezes (13,6\%). No Museu Paulista, as palavras "história/histórico" foram citadas 168 vezes $(46 \%)$ e "arte" cinco vezes $(1,4 \%)^{17}$. Ou seja, proporcionalmente, os visitantes da Pinacoteca consideraram os aspectos históricos muito mais relevantes nas exposições do que os visitantes do Museu Paulista os aspectos artísticos.

Entretanto, os visitantes do Museu Paulista citaram com bastante freqüência as obras de arte do museu como o que "mais gostaram" na visita: "quadros/telas" foram citados 45 vezes, "arte" 12 e "pinturas" 10, enquanto "história/histórico" foram citados apenas 19 vezes. Nas respostas escritas pelos visitantes que "gostaram" das obras de arte, elas foram geralmente citadas de forma genérica, como qualquer outro objeto do museu, por exemplo: "pinturas"; "quadros", "telas"; "os quadros de tamanho grande e as louças"; "quadros, armaduras e carros antigos"; "obras de arte e arquitetura".

Entre as pinturas citadas, destaque para a obra Independência ou Morte!, de Pedro Américo (1 3 citações): "quadro da Independência"; "apuramos com louvor a magistral obra de Pedro Américo"; "quadro da Independência, cabelo da Princesa Isabel"; "quadro Independência ou Morte, ânforas com águas dos rios, cotidiano (utensílios)".

Uma possível explicação é que, também para os visitantes, os "quadros", as obras de arte são apreciadas como documento histórico e não por seus aspectos estéticos. Uma boa parte das obras de arte faz parte da própria decoração interna do prédio, projetada por Taunay desde o início de sua gestão, em 1917.

Ao discorrer sobre a formação das coleções "históricas" do Museu Paulista, Ulpiano Bezerra de Meneses comenta que a utilização das pinturas como documentos iconográficos está baseada numa "concepção visual da História":

A importância da iconografia se funda numa concepção visual da História, magistra vitae, e no poder de evocação e celebração da imagem. Por isso, o museu não apenas coleta documentos iconográficos, como passa a produzi-los, encomendando-os a pintores e escultores, segundo prescrições bem definidas (MENESES, 1994b, p. 576).

A própria museografia - com exposições recentes somadas a elementos que permaneceram desde a gestão de Taunay - reforça essa proposta, geralmente apresentando as obras como parte da discussão de acontecimentos históricos. Por exemplo, as telas relacionadas ao Descobrimento são apresentadas na sala Descobrimentos Imaginados, inseridas em discussões sobre a imagem do índio, a evangelização, etc. e acompanhadas por vitrinas com outros objetos - como armas e instrumentos de trabalho - que também contextualizam a discussão sobre o tema. Certamente, a proposta da sala não é ilustrar o Descobrimento com as obras de arte. Os textos que acompanham as obras procuram auxiliar o visitante a fazer uma leitura crítica, observando seus elementos formais e conteúdos e inserindo-as no universo de sua produção. Entretanto, aqueles visitantes menos preparados que não se interessam em ler os textos ou mesmo aqueles que os lêem podem, e provavelmente vão, fazer leituras que não necessariamente
17. Há outras palavras que também fazem referência à História que aparecem na fala dos visitantes dos dois museus:"passado" foi citada por $13 \mathrm{vi}$ sitantes da Pinacoteca e 32 do Museu Paulista "época" foi citada por nove respondentes da Pinacoteca e 10 do Museu Paulista; "antiga/antigüidade" foi citada por dois respondentes da Pinacoteca e por nove do $\mathrm{Mu}$ seu Paulista. 
18. A dificuldade de "ler" uma pintura como um documento histórico levou o Museu Paulista a incluir esse tema em sua publicação de 1992 voltada para professores (MENESES, 1992a.).

19.Acredito que a autora referiu-se aqui a museus e centros de ciências que não apresentam exposi ções com enfoque histórico, e os museus de his tória das ciências estariam excluídos dessa concep ção de museu de ciência "a-histórico". coincidem com a proposta pela exposição, o que é bom, pois um dos papéis do museus é estar aberto para diversas leituras ${ }^{18}$.

A força das imagens faz crer que elas representam os eventos do passado como verdade/realidade. As esculturas e pinturas são observadas em seus conteúdos, com destaque para os personagens e suas ações, sem maior interesse nas questões estéticas. Busca-se a História e/ou o passado ao olhar para elas.

Os diferentes olhares provocados pelos diversos tipos de museus foram explorados por Monique Sicard ao observar os públicos do Grand Palais, de Paris, que abriga dois museus com museografias e temáticas diferentes - obras de arte no chamado Grand Palais (criado em 1900) e modelos, experiências e maquetes científicas no Palais de la Découverte (criado em 1937). A autora registrou experiências muito diversas:

Dans la première exposition, on se recueille devant les objets; les paroles ne s'échangent qu'à voix basse. Les explications - écrites - sont réduites au minimum.

Dans la seconde, on s'émerveille et l'on s'effraie mais l'étonnement sert de pretexte à l'explication; on échange à voix haute et ces bavardages-là ont valeur de transmission. L'exercice de l'observation, les démonstrations, prennent le pas sur les objets. Le public est jeune (SICARD, 2001 p. 41 ).

Monique Sicard busca na História a raiz de tais diferenças. A visão do que deveria ser um museu de arte e um museu de ciência na França teve fundamento importante no período iluminista. No fim do século XVIII, buscou-se dessacralizar os objetos de arte, dando-lhes o mesmo valor que os objetos científicos e pedagógicos. Entretanto, nos séculos XIX e XX, os objetos artísticos passaram a ser mais valorizados que os outros e, em 1945, essa distinção foi oficializada: os museus eram somente os de arte, história e arqueologia e passaram a ficar sob tutela do Ministério da Cultura. Já os museus de ciências ("museum") ficaram sob responsabilidade do Ministério da Educação, Pesquisa e Tecnologia da França (SICARD, 2001 , p. 42-43).

Para Sicard, as diferenças também são de olhar e de visão de mundo diferentes, que geram soluções museográficas diversas. Os museus de arte tratam da memória e têm a missão de instituir a imortalidade, enquanto os museus de ciência são freqüentemente a-históricos, mais voltados para o público infantojuvenil e se sentem investidos do dever de educação ${ }^{19}$. Além disso, o conceito de cultura de cada um seria diferente:

La première mission des musées des sciences est de faire connaître, comprendre - voir accepter - les developpements scientifiques. Celle des musées d'art est d'installer les fondements d'une histoire collective. La définition de la culture qui em resulte n'est pas la même. Dans le premier cas, il s'agit de réconcilier les citoyens avec les évolutions du monde contemporain. Dans le second, de créer des réferences, de faire histoire (SICARD, 2001, p. 43).

Partindo do pressuposto de que o museu/exposição é uma mídia, Sicard afirma que "un même objet presenté dans um musée des sciences ou dans 
un musée de Beaux Arts ne présente pas, pour celui qui vient le voir, la même signification". Ela exemplifica: Fotografias tiradas em laboratórios científicos foram apresentadas no Palais de Tokyo lexposição Images d'un autre monde, em Paris, 1991-1992) como obras de arte. Os autores das fotografias foram valorizados, suas fotografias foram apreciadas como obras de arte, e os visitantes eram levados a perguntar "quem fez?", "quando fez?" e não "o que é?" ou "como fez?", estas últimas perguntas típicas de um museu de ciência.

As trajetórias dos museus de arte e de ciência no tempo foram solidificando as noções de que a Arte faz parte de um mundo acima da realidade cotidiana, que é superior e só pode ser compreendida por uma minoria iniciada, que conhece sua história, enquanto a Ciência é altamente voltada para o mundo prático e imediato e não exige o conhecimento de sua história para a compreensão dos fenômenos estudados.

Certamente não concordo com a desvalorização da História para a compreensão da Ciência, assim como não aceito que a arte só possa ser compreendida por alguns poucos iniciados. Entretanto, parece-me que muitos museus têm colaborado para a continuidade dessas crenças e isso pode ser evidenciado pelo estudo dos seus públicos e da avaliação de suas exposições.

A taxonomia dos museus apresenta problemas, assim como ocorre com a compartimentação das disciplinas no ensino e na pesquisa. Se para aqueles que estudam os museus essa diferenciação parece problemática, acredito que para o público visitante exista uma clara diferenciação, que se inicia no próprio prédio, passando pela museografia, pelo acervo e exposições temporárias, completando-se pela ação educativo-cultural.

No caso dos museus estudados, a predisposição do olhar para a Arte ou para a História, essa noção clara de que tal museu é histórico e tal é de arte surge também na forma de valorização dos prédios, aparecendo como resposta de "o que mais gostou". No Museu Paulista, 10\% afirmaram que o que mais gostaram foi o "prédio, a arquitetura", valorizados como documento histórico. $\bigcirc$ prédio do Museu Paulista foi construído para ser um monumento à Independência do Brasil, celebrar um marco da história nacional e posteriormente seu uso foi modificado para abrigar o museu20. "Andar por uma construção tão antiga e imaginar como as pessoas viviam antigamente", assim se expressa um dos visitantes sobre o prédio do Museu Paulista. Muitas pessoas acreditam que D. Pedro e sua família teriam morado no local. Entre as respostas "do que sentiu falta no Museu Paulista" são inúmeras que pedem "como eram os cômodos na época" como se a família real tivesse vivido no local. Também aparecem inúmeros pedidos para ver "mais objetos pertencentes à família real" como jóias, a coroa de D. Pedro, "os pertences do imperador", sendo que um dos visitantes desejava ver "o quarto do rei". Já a arquitetura do prédio da Pinacoteca, construído em 1900 com projeto de Ramos de Azevedo para abrigar o Liceu de Artes e Ofícios, citada por $6 \%$ dos respondentes como o que mais gostaram, é apreciada como obra de arte e de arquitetura ${ }^{21}$.
20. Cecília Helena S. Oliveira (2002) descreve a construção do monumento e do marco de 7 de Setembro para a história nacional.

21.Algumas das respostas dos visitantes da Pinacoteca foram: "ambiente da Pinacoteca e exposições temporárias"; "da exposição, do espaço da Pinacoteca que é lindo!”; "nada em particular, acho sempre bom visitar a Pinacoteca.A própria arquitetura do espaço já é atraente"; "o aspecto 'céu aberto' do prédio, a multiplicidade de exposições e temáticas e o acervo de excelente qualidade"; "janelas, tijolinhos à vista."; "restauração interna que está bonita e o original rústico da arquitetura externa do prédio". 
Os estudos de público e avaliações de exposições em museus encaram o visitante como um participante ativo da relação museal. Por meio de observação, entrevistas, questionários, depoimentos, conversas telefônicas, esses estudos têm trazido a "voz" do visitante de museus, na busca do aperfeiçoamento do processo comunicacional promovido pelas exposições (ALMEIDA, 2002; STUDART et al., 20031.

As avaliações das exposições mostraram que cada visitante constrói sua própria exposição ao selecionar seu percurso, de acordo com seu desejo, suas motivações, suas necessidades, seus companheiros, entre outras variáveis. Assim, na elaboração da exposição, procura-se cada vez mais conhecer o perfil, os conhecimentos prévios, os desejos, as necessidades do visitante/receptor.

As pesquisas de público em museus, geralmente, estão baseadas em modelos de comunicação, explícitos ou implícitos, que vão nortear as teorias e metodologias. Sempre procurei utilizar um modelo comunicacional dialógico, no qual emissor e receptor participam com seus conjuntos textuais, a partir de suas culturas próprias. Nesse sentido, levam-se em conta as diferenças culturais entre emissor e receptor e todo o contexto histórico-social em que se realiza o ato comunicacional. As motivações, os interesses e opiniões dos visitantes/ receptores são fundamentais para a compreensão do processo de comunicação que ocorre no museu (ALMEIDA; LOPES, 2003).

Outro modelo utilizado foi o da "experiência museológica" proposto por Falk e Dierking. Ao propor investigar o que seria aprender em museu e em quais situações seria possível afirmar que houve aprendizagem, os autores apresentaram o "modelo contextual de aprendizagem" em museu ("contextual model of learning"). Nesse modelo, a visita ao museu é interpretada como a intersecção de três contextos: pessoal, físico e sociocultural. $\bigcirc$ modelo tornou ainda mais visíveis as relações que ocorrem durante a visita ao museu e levou em conta também todos os antecedentes da visita e fatos posteriores relevantes, incluídos no chamado "contexto pessoal" (FALK; DIERKING, 1992, p. 2). Além disso, o modelo foi inserido na dimensão temporal, enfatizando a aprendizagem como um processo contínuo. As pesquisas indicam que elementos vistos em uma exposição podem servir de base para a construção de um novo conhecimento, muitos meses ou até anos depois da experiência da visita (FALK; DIERKING, 20001.

No modelo, o contexto sociocultural abrange todos os contatos com indivíduos ou grupos durante a visita, podendo ser os grupos dos quais o visitante participa, os visitantes de outros grupos ou ainda contatos de servidores do museu ou qualquer outra pessoa. $\bigcirc$ contexto físico envolve tanto a exposição como o prédio do museu, seus arredores, enfim, o ambiente no qual se dá a interação.

contexto pessoal engloba todas as motivações, conhecimentos e crenças do visitante, sua seleção e escolha de percurso, atitudes durante a visita 
e os eventos e experiências de reforço posteriores fora do museu. Nas pesquisas que tenho feito procuro destacar elementos desse contexto que levam à valorização ainda maior da figura do visitante/receptor no processo comunicacional e de seu papel para o aperfeiçoamento dos programas desenvolvidos pelos museus.

Pretendo também enfatizar a importância da cultura local para a formação do "contexto pessoal" e para a construção de cada experiência do visitante no museu.

Motivações para visitar museus

Segundo Falk e Dierking (1 992) haveria três tipos de motivações para visitar um museu: 1) razões sociais e recreativas, ou seja, para se divertir, estar junto em local agradável; 2) razões educacionais; 3) razões "reverenciais" (reverential reasons), a busca de objetos únicos, monumentos sacralizados.

Os autores chamam a atenção para o fato de que as pesquisas com os visitantes podem ocultar certas razões para visitação. Eles usam como exemplo o zoológico. As pessoas podem responder que o motivo para a visita é puramente diversão, mas certamente têm expectativa de ver animais e, respondendo sua curiosidade sobre eles, também acabarão aprendendo. Assim, aprender sobre animais estaria implícito nas motivações e não seria necessário explicitar (FALK; DIERKING, 1992, p. 14).

A importância da motivação para a compreensão do processo da visita ao museu já havia sido destacada por outros autores, mas Falk e Dierking valorizaram-na como elemento fundamental da experiência no museu e associaram-na às expectativas na composição de parte do "contexto pessoal". Assim, as expectativas e motivações estão intimamente ligadas ao planejamento da visita.

No trabalho de Marilyn Hood (1983), constantemente citado na bibliografia da área de avaliação em museus, a autora discute as motivações para a visita a museus, comparando-os com outros espaços de lazer, aprendizagem e socialização.

Nos seus estudos sobre visitantes e não-visitantes de The Toledo Museum of Art, nos Estados Unidos, a autora definiu três categorias de acordo com a freqüência ao museu: "público freqüentador", que visitava o museu pelo menos três vezes ao ano; "público eventual", que fazia uma a duas visitas por ano; "não público", que passava dois anos sem visitar o museu (HOOD, 1983). De acordo com as pesquisas, a escolha de ir ao museu ou não estaria diretamente relacionada aos critérios para escolher atividades de lazer, assim definidos por Hood: 1) estar com pessoas/interação social (being with people); 2) fazer algo que valha a pena para si ou para outras pessoas; 3) sentir-se confortável e à vontade no ambiente; 4) ser desafiado por novas experiências; 5) ter oportunidade de aprender; 6) participar ativamente. 
22. A estudante de estatística Natália Teixeira Pinto, Unicamp, auxiliou na análise estatística dos dados.

23. No terceiro domingo de cada mês, o ingresso para o Museu Paulista é gratuito. O Museu de Zoologia cobra ingresso todos os dias, e a Pinacoteca do Estado, no período da pesquisa, era gra tuita.
A autora identificou que aqueles que eram freqüentadores $114 \%$ dos respondentes) visitavam o museu para aprender, para enfrentar desafios e fazer algo que valia a pena no tempo de lazer. Já os visitantes ocasionais (40\%) e os que não visitavam (46\%) o museu gostavam de sair para estar com pessoas, participar ativamente e sentir-se à vontade, o que não imaginavam ser possível em um museu de arte. Para Hood, foi uma surpresa o fato de os visitantes ocasionais terem valores e interesses mais próximos dos não participantes do que dos freqüentadores, uma vez que acreditava que, independentemente do número de visitas, os valores eram semelhantes.

Os conceitos de público freqüentador, ocasional e não-visitante de Hood (1983) foram amplamente aceitos e aplicados em outras pesquisas em várias partes do mundo. Para o caso do Brasil, precisamos nos perguntar se podemos adotar um conceito de visitante ocasional para alguém que foi uma a duas vezes no ano a um museu, assim como Hood fez para a comunidade de Toledo. Nos Estados Unidos e na Europa, o número de museus é infinitamente maior que no Brasil, assim como sua diversidade e, além disso, o hábito cultural e social de visitá-los está incorporado à cultura das classes médias urbanas muito mais do que no Brasil. Será que não deveríamos criar nossos padrões de freqüentadores eventuais e não-visitantes? Para isso temos que ampliar o número de estudos.

As categorias propostas por Hood e Falk serviram de base para duas das questões de minha pesquisa. Uma delas, a questão (fechada) número 3 (ver tabela na p. 279) "Por que veio hoje a(o)...?" apresentava várias alternativas: a alternativa "trazer familiares, amigos" corresponderia a categoria "estar com pessoas/interação social" (being with people) e "razões sociais e recreativas"; a alternativa "trabalho escolar/professor recomendou" tem relação com "ter oportunidade de aprender" e "razões educacionais"; a categoria "assunto interessa/gosta de museus" contém, em parte, "fazer algo que valha a pena para si ou para outras pessoas". "Curiosidade de conhecer o(a)..." poderia incluir "ser desafiado por novas experiências" ou até "razões reverenciais", assim como ver "exposição temporária". As categorias "para passear", "outras atividades oferecidas", "mora/trabalha perto/veio ao parque" não apresentam relação tão clara com apenas uma das categorias de Hood ou Falk.

Para o Museu Paulista e o Museu de Zoologia, o passeio em grupo/família (estar com pessoas/razões sociais) é preponderante (38\% e 47\%). A alternativa "assunto interessa" aparece com índices significativos nos três museus (MZ: 21\%, MP: 23\% e Pina: 37\%), sendo significativamente maior para a Pinacoteca ${ }^{22}$.

"Curiosidade" e "passear" também são motivações para a visita. No caso do MP, "estar no parque e resolver entrar" também aparece. Isso talvez seja ainda mais fortalecido pelo fato do domingo da semana pesquisada ter o ingresso gratuito ${ }^{23}$.

Na Pinacoteca, a exposição temporária aparece como segunda motivação mais forte, $27 \%$, indicando que o museu de arte atrairia por "razões reverenciais". Falk e Dierking consideram que essas seriam, possivelmente, razões mais fortes para museus de arte: 
Anthropologist Nelson Grabun has alluded to the public's need for reverential experience, "a personal experience with something higher, more sacred, and out of the ordinary than home and work are able to supply." The museum can offer something akin to a religious experience, and can be a place of "peace and fantasy" where the visitor can escape the mundane, worka-day world. There are few data to support or refute this idea, but Ken Yellis was able to find evidence that, among certain frequent visitors to art museums, at least, the "reverential" motivation is considerable. In a series of focus group interviews conducted at eleven major art museums, "reverence" emerged as an important ingredient for at least some of the visitors (FALK; DIERKING, 1992, p. 15-16).

\begin{tabular}{|l|c|c|c|}
\hline Por que veio a(o) ... hoje? & MZ & MP & Pina \\
\hline Trazer familiares, amigos & $46,7 \%$ & $38,3 \%$ & $14 \%$ \\
\hline Trabalho escolar/prof. recomendou & $0,9 \%$ & $1,1 \%$ & $1 \%$ \\
\hline Outras atividades oferecidas & $0 \%$ & $0,9 \%$ & $0,7 \%$ \\
\hline Assunto interessa/gosta museus & $21 \%$ & $23,5 \%$ & $37 \%$ \\
\hline Mora/trabalha perto/veio ao parque & $3,7 \%$ & $9,7 \%$ & $2,9 \%$ \\
\hline Exposição temporária & $0,5 \%$ & $0,2 \%$ & $27,3 \%$ \\
\hline Curiosidade de conhecer alo) & $15 \%$ & $11,6 \%$ & $7,6 \%$ \\
\hline Para passear & $7 \%$ & $11,8 \%$ & $6 \%$ \\
\hline Outros & $5,1 \%$ & $2,6 \%$ & $3 \%$ \\
\hline Não respondeu & $0 \%$ & $0,4 \%$ & $0,3 \%$ \\
\hline Total & $100 \%$ & $100 \%$ & $100 \%$ \\
\hline
\end{tabular}

A identificação do museu de arte como um ambiente de reverência aparece nas respostas obtidas por Maria Cristina Freire (1993), ao perguntar aos visitantes do Museu de Arte Contemporânea da Universidade de São Paulo (MAC/USP) que tipo de lugar o museu parecia. Biblioteca, loja e igreja foram algumas das respostas obtidas. Para a autora, a associação com a biblioteca evocaria o lado público de acesso a bens culturais e traria a analogia de acervo de obras de arte do museu com os acervos de livros das bibliotecas. Por outro lado, a associação com loja traria o valor econômico das obras e, no caso de igreja, a relação de reverência (FREIRE, 1993).

Como a pesquisa de campo foi realizada no período das férias de verão (Museu de Zoologia e Pinacoteca) e na primeira semana de aulas (Museu Paulista), a motivação para realização de trabalho escolar é muito pequena. Entretanto, nas respostas sobre os "benefícios da visita" houve um alto índice de 
respostas referentes ao valor educacional. O sentido de "educacional" aqui me parece bastante amplo, o que pelas características dos museus, instituições tipicamente dedicadas à educação não formal, não representaria um problema. O entendimento mais claro do que seria para cada visitante "educacional" será obtido inicialmente com a leitura de suas "falas" e, também, com a continuidade da pesquisa e realização de novas entrevistas.

Para a tabulação da questão 14 (aberta) "Na sua opinião, quais os benefícios de uma visita a esse museu?", utilizamos as categorias de Hood e Falk e outras definidas pelas respostas obtidas, conforme apresentado na tabela abaixo.

\begin{tabular}{|l|c|c|c|}
\hline $\begin{array}{l}\text { Na sua opinião, quais os } \\
\text { benefícios de uma visita? }\end{array}$ & $M Z$ & $M P$ & Pina \\
\hline Educacionais/instrucionais & $60,9 \%$ & $47,9 \%$ & $29,5 \%$ \\
\hline Culturais & $12,6 \%$ & $27 \%$ & $30,2 \%$ \\
\hline Divertimento/lazer/prazer & $7,2 \%$ & $2,6 \%$ & $13,4 \%$ \\
\hline Ver coisas novas/belas & $4,8 \%$ & $1,3 \%$ & $8,3 \%$ \\
\hline Conhecer local novo/turismo & $0 \%$ & $0,6 \%$ & $1 \%$ \\
\hline Estar com família/amigos/colegas & $2,4 \%$ & $0,6 \%$ & $1 \%$ \\
\hline Outros & $0 \%$ & $1,7 \%$ & $6,2 \%$ \\
\hline Não respondeu & $12,1 \%$ & $18,5 \%$ & $10,4 \%$ \\
\hline Total & $100 \%$ & $100 \%$ & $100 \%$ \\
\hline
\end{tabular}

Como já dito anteriormente, a visão do museu como um espaço educacional é muito freqüente entre os visitantes dos três museus, com uma significativa preponderância no Museu de Zoologia.

A combinação das motivações alegadas nas respostas à questão 3 (motivo da visita) com os benefícios da 14 evidenciam de forma mais completa as motivações e expectativas dos visitantes. Dos respondentes do Museu Paulista que afirmaram estar visitando para trazer/acompanhar familiares ou amigos, $56 \%$ disseram ser "educacionais" os principais benefícios da visita, enquanto apenas $0,6 \%$ disse estar com família/amigos. No caso do Museu de Zoologia, daqueles que tiveram como motivação trazer/acompanhar familiares e amigos, $67 \%$ consideraram os benefícios educacionais mais importantes, e 3,7\% apresentam o fato de estar com a família.

Ou seja, esses visitantes consideram o Museu Paulista e o Museu de Zoologia espaços de interação social onde se pode aprender com familiares e amigos. Esses resultados confirmam as observações já citadas de Falk e Dierking 
(1992) nas quais as motivações declaradas geralmente deixam implícitos os motivos "óbvios", como ver animais em um zoológico, ver obras de arte em um museu de arte, ou mesmo aprender sobre animais em um zoológico. (FALK; DIERKING, 1992, p. 14)

No caso da Pinacoteca, a maior parte dos respondentes afirmou visitála porque o "assunto interessa/gosta de museus de arte", e os principais benefícios da visita são os culturais (30\%) seguidos dos educacionais (29\%). É importante notar que há um número significativo que considerou o lazer e o prazer como principais benefícios da visita (13\%), percentual muito superior aos $7 \%$ do $M Z$ e $3 \%$ do MP. No cruzamento das motivações com os benefícios, verifica-se que, seja qual for a motivação, com maior freqüência os visitantes da Pinacoteca consideram os benefícios culturais como os mais importantes. Os benefícios educacionais vêm sempre em segundo lugar, confirmando a idéia inicialmente apresentada de que as pessoas consideram os museus de arte mais como um espaço de cultura do que um espaço de aprendizagem, o qual é identificado na maioria das vezes com os museus de ciências e de história.

A companhia para a visita parece ser um dos definidores do tipo de atividade de lazer a realizar e do tipo de museu a visitar.

As motivações estão ligadas ao conteúdo das exposições e também ao tipo de experiência que possibilitam. Visitas de famílias a centros de ciências sugerem que são motivadas pelos pais que querem passar seus interesses na área para seus filhos, ou seja, para que seus filhos aprendam. Ou ainda como uma forma de lazer educacional, possibilitando interação entre as diversas pessoas da família, num passeio agradável.

Em outras pesquisas realizadas por mim, algumas das questões aqui discutidas já haviam aparecido. Na avaliação da exposição do Museu Biológico do Instituto Butantan, entrevistei 125 visitantes espontâneos à saída do museu ${ }^{24}$. Perguntados sobre o motivo da visita, 58\% responderam que foram a passeio e/ou turismo, 14\% foram acompanhar outras pessoas e 5\% estavam na região e resolveram entrar. Ou seja, o museu era um espaço de lazer social para a maioria dos respondentes, que lá iam com amigos ou familiares para se divertir. Isso pode ser confirmado pelo fato de que apenas 12\% dos respondentes tinham ido sozinhos, enquanto $45 \%$ foram acompanhados de familiares e $23 \% \mathrm{com}$ amigos.

A pesquisa realizada no Museu Lasar Segall (MLS) mostrou que ele é mais visitado por pessoas acompanhadas (64\%), sendo que a maior parte (72\%) estava acompanhada por apenas uma pessoa. Isso indicaria ser o museu um local mais voltado para a contemplação do que para a socialização. Porém, quando verificadas as motivações para visitar o MLS, "passear e conhecer o museu" (29\%) e "acompanhar pessoas" (17\%) aparecem como as principais razões, indicando que o museu é um espaço de lazer e socialização para muitos dos respondentes.

Quando cruzamos as motivações com o número de visitas ao MLS, obtivemos maior percentual para o motivo "conhecer/passear" (37\%) para os que estavam fazendo a primeira visita (63\% dos respondentes), enquanto que
24. Os dados citados sobre os visitantes do $\mathrm{Mu}$ seu Biológico do Instituto Butantan foram obtidos durante pesquisa de mestrado, porém parte deles é inédita, pois não é citada na dissertação (ALMEIDA, 1995). 
25. Os resultados da pesquisa em 14 museus do Observatoire Permanent du Public da França indicam que, como em outros casos, os museus de arte foram os mais visitados por pessoas desacompanhadas. Entre eles o Musée National du Moyen Âge - Thermes de Cluny teve $69 \%$ dos visitantes desacompanhados ou em duplas e o Musée des Beaux-Arts et d'Archéologie de Rennes teve $67 \%$ dos visitantes desacompanhados ou em duplas. Para os autores, a explicação seria dada pe lo fato de que a relação com a arte, com as obras "é de ordem mais íntima que a relação com as técnicas e a história" (LEHALLE; MIRONER, 1993 , p. 67)

para aqueles que o visitavam pela segunda ou terceira vez, a motivação principal foi "acompanhar pessoas" (27\% e 58\%, respectivamente). A exposição temporária apareceu como principal motivo da visita daqueles que estavam indo pela quarta vez (50\%) ao MLS (ALMEIDA, 2001 ).

Assim, outra variável para a motivação está relacionada ao fato de se conhecer ou não o museu anteriormente. No caso daqueles que já foram e gostaram, é comum o interesse em levar outras pessoas para conhecêtlo, evidenciando a importância da qualidade da visita para o retorno aos museus.

Apesar de muitas pesquisas indicarem que os museus de arte são mais visitados por pessoas desacompanhadas, por permitirem experiências de contemplação e fruição individual, outras os indicam como um local de interação social e de lazer familiar.

As pesquisas do público do Museu do Louvre (Observatoire Permanent du Public, 1999 e 2000) têm evidenciado o museu como um espaço eminentemente social. Dos respondentes (com idade acima de 15 anos) em 1999, 94\% visitavam acompanhados, sendo 33\% em pares, 32\% em grupos de três, quatro ou cinco pessoas e $27 \%$ de seis ou mais. Quase metade (49\%) visitava com familiares, e $30 \%$ foram com amigos. Se comparados com outros museus de arte, os resultados do Louvre são divergentes ${ }^{25}$, porém isso pode ser explicado pelo fato de ele ser uma importante atração turística e um lugar para "mostrar para alguém", sejam crianças e jovens (motivo de visita de 12,5\% dos visitantes de 1998) ou parentes e amigos (motivo de 16\% dos visitantes de 1998). O Louvre é um espaço de socialização, e nesse ponto da pesquisa temos por variável significativa a importância do museu como atração turística.

Nos três museus pesquisados, a maioria dos visitantes foi acompanhada.

\begin{tabular}{|l|c|c|c|}
\hline Com quem veio a(o) ... & MZ & MP & Pina \\
\hline Grupo turismo & $0,6 \%$ & $2,8 \%$ & $0,2 \%$ \\
\hline Familiares & $73,7 \%$ & $63,3 \%$ & $42,8 \%$ \\
\hline Amigos & $12,9 \%$ & $19 \%$ & $27,5 \%$ \\
\hline Colegas escola/trabalho & $2,3 \%$ & $1,5 \%$ & $3 \%$ \\
\hline Sozinhola) & $6,4 \%$ & $8,1 \%$ & $20 \%$ \\
\hline Outros & $3,5 \%$ & $4,5 \%$ & $5,8 \%$ \\
\hline Não respondeu & $0,6 \%$ & $0,9 \%$ & $0,7 \%$ \\
\hline Total & $100 \%$ & $100 \%$ & $100 \%$ \\
\hline
\end{tabular}


No MZ e MP, a visita em família lidera (74\% e 64\%), assim como na Pinacoteca, só que em menor índice (43\%). A visita com amigos teve o segundo maior índice nos três museus (MZ: 13\%, MP: 19\% e Pina: 27\%), com freqüência significativamente maior na Pinacoteca. $\bigcirc$ museu de arte aparece como espaço de interação social não só familiar, mas também entre amigos. Há também um número significativo de visitantes desacompanhados $-20 \%$, diferentemente dos $6 \%$ do MZ e dos 8\% do MP. Nesse caso, parece que se segue o padrão internacional, ou seja, nos museus de arte há maior freqüência de pessoas desacompanhadas.

\begin{tabular}{|l|c|c|c|}
\hline Número de acompanhantes & $M Z$ & $M P$ & Pina \\
\hline Um & $27,2 \%$ & $39,7 \%$ & $62,4 \%$ \\
\hline Dois & $33,5 \%$ & $23,4 \%$ & $16,7 \%$ \\
\hline Três & $18,4 \%$ & $17,8 \%$ & $10 \%$ \\
\hline Quatro & $10,1 \%$ & $8,9 \%$ & $3,6 \%$ \\
\hline Cinco & $4,4 \%$ & $3,3 \%$ & $1,5 \%$ \\
\hline Mais de cinco & $6,3 \%$ & $6,5 \%$ & $5,3 \%$ \\
\hline Não respondeu & $0 \%$ & $0,5 \%$ & $0,4 \%$ \\
\hline Total & $100 \%$ & $100 \%$ & $100 \%$ \\
\hline
\end{tabular}

Essa tendência fica ainda mais clara quando verificamos quantos acompanhantes havia: $62 \%$ daqueles que foram acompanhados na Pinacoteca estavam apenas com um acompanhante, enquanto eram 40\% no Museu Paulista e $27 \%$ no Museu de Zoologia.

No $M Z$ e MP, o grupo entre três e cinco pessoas foi de 33\% e $31 \%$ enquanto na Pinacoteca foi de 15\%, reforçando o padrão de grupos maiores para os museus de ciências e história em comparação com os de arte.

No Museu de Zoologia, 50\% dos acompanhantes estão entre 0 e 15 anos de idade, indicando uma clara preferência dos adultos por trazer o público infanto-juvenil a esse espaço. Já no Museu Paulista essa faixa, também a mais freqüente, representa 29\% dos acompanhantes. Na Pinacoteca, ela só corresponde a $13 \%$ dos acompanhantes, a quarta mais freqüente.

Esses resultados parecem confirmar que o museu de ciência atrai mais público infanto-juvenil do que o museu de arte. Já o Museu Paulista apresenta um perfil intermediário, tendo freqüência de público infanto-juvenil alta, porém menor que o Museu de Zoologia, e índices maiores que o Museu de Zoologia de acompanhantes acima de 16 anos, porém menores que os da Pinacoteca. No caso da Pinacoteca, a maior parte das pessoas acompanhadas de apenas 
uma pessoa parece ser casais ou amigos de idade parecida (adultos), pois o perfil de idade dos respondentes é semelhante ao dos acompanhantes, o que não ocorre para o MZ e MP.

\begin{tabular}{|l|c|c|c|}
\hline Idade acompanhante(s) - (anos) & $M Z$ & $M P$ & Pina \\
\hline O a 15 & $50 \%$ & $29,4 \%$ & $12,7 \%$ \\
\hline 16 a 20 & $5,6 \%$ & $12,7 \%$ & $17,5 \%$ \\
\hline 21 a 30 & $14,3 \%$ & $19,4 \%$ & $18,7 \%$ \\
\hline 31 a 40 & $11,4 \%$ & $12,5 \%$ & $17,4 \%$ \\
\hline 41 a 50 & $5,6 \%$ & $8,1 \%$ & $12,6 \%$ \\
\hline 51 a 60 & $3,6 \%$ & $4,5 \%$ & $8 \%$ \\
\hline Mais de 60 & $5,1 \%$ & $2,9 \%$ & $5,2 \%$ \\
\hline Não respondeu & $4,4 \%$ & $10,5 \%$ & $8 \%$ \\
\hline Total & $100 \%$ & $100 \%$ & $100 \%$ \\
\hline
\end{tabular}

Hábitos de consumo cultural

As pesquisas costumam evidenciar relações entre os critérios de escolha de atividades de lazer, hábitos de consumo cultural e grupos de pessoas. Nesse sentido, os estudos de públicos de museus costumam inserir perguntas sobre o hábito de visitar museus e sobre o consumo cultural dos respondentes. Normalmente encontram-se associações interessantes.

Em pesquisa de Willian Gudykunst e colegas sobre as preferências de lazer dos residentes de New England, foi possível categorizar os respondentes de acordo com sua opção pelas atividades de lazer em três grupos: $\bigcirc$ primeiro, denominado "cultural" ou "intellectual", costuma ir a concertos, teatros, cinemas, lê por prazer, viaja para turismo e vai a museus (museum-goers). O segundo, chamado de "organization" ou "club", não é de visitantes regulares de museus e o terceiro "participation" também não é de freqüentadores de museus, tendo preferência por esportes, jogos e bailes (FALK; DIERKING, 1992).

No estudo de Cristina Freire, o público visitante do Museu de Arte Contemporânea/USP mostrou como atividade preferida ir ao cinema, sendo que $36 \%$ disseram ir semanalmente. No caso de museus, $15,3 \%$ declararam ir a cada semana e somente $7,2 \%$ iam ao teatro com essa assiduidade (FREIRE, 1993). 


\begin{tabular}{|l|c|c|c|}
\hline No tempo livre, o que você mais faz? & MZ & MP & Pina \\
\hline Ir ao cinema & $14,3 \%$ & $15,4 \%$ & $19,2 \%$ \\
\hline Ir ao teatro & $2,8 \%$ & $3,6 \%$ & $5,4 \%$ \\
\hline Passear parque & $12,2 \%$ & $10,5 \%$ & $6,6 \%$ \\
\hline Assistir show música/dança & $2,6 \%$ & $4,0 \%$ & $3,9 \%$ \\
\hline Ir ao shopping & $11,6 \%$ & $13,2 \%$ & $7 \%$ \\
\hline Visitar museus/exposições & $7,5 \%$ & $4,7 \%$ & $10,3 \%$ \\
\hline Ler/ouvir música & $13,4 \%$ & $13,6 \%$ & $17,2 \%$ \\
\hline TV/vídeo/DVD/navegar internet & $13,2 \%$ & $13,5 \%$ & $10,9 \%$ \\
\hline Praticar esportes/ir ao clube & $6,5 \%$ & $6,1 \%$ & $5 \%$ \\
\hline Ir ao restaurante & $4,5 \%$ & $5,8 \%$ & $6 \%$ \\
\hline Receber/visitar amigos/parentes & $9 \%$ & $7,9 \%$ & $6,6 \%$ \\
\hline Outros & $2,6 \%$ & $1,3 \%$ & $1,9 \%$ \\
\hline Não respondeu & $0 \%$ & $0,4 \%$ & $0,1 \%$ \\
\hline Total & $100 \%$ & $100 \%$ & $100 \%$ \\
\hline
\end{tabular}

Nos três museus pesquisados, "ir ao cinema" aparece como uma das atividades preferidas, havendo uma freqüência significativamente maior na Pinacoteca: 14\% no MZ, 15\% no MP e 19\% na Pina, assim como "ler/ouvir música" (13\%, 14\% e 17\%, respectivamente).

Os respondentes do MZ e MP vão com freqüência a parques e shopping centers, diferentemente dos visitantes da Pinacoteca que vão com maior freqüência a exposições e museus (10\%).

Para os três museus, "viajar" aparece mais freqüentemente na opção "outros" motivos. Praticar atividades de artes plásticas surge nos três museus, mas com maior freqüência entre os respondentes da Pinacoteca.

As freqüências das categorias "ver TV/vídeo", "ir ao restaurante", "praticar esportes" e "receber amigos" não apresentaram diferença significativa entre os museus.

Como citado anteriormente, os critérios para escolha de atividades de lazer passam por preferências ligadas às companhias e ao que é oferecido pela atividade. Certamente as pessoas variam os critérios, ampliando as possibilidades de lazer. Os freqüentadores da Pinacoteca, um museu de arte, vão mais ao teatro 
e a outros museus e exposições, fato confirmado pelas respostas a outra questão, que solicitava a indicação dos museus visitados nos últimos dois anos a partir de uma lista dada.

\begin{tabular}{|l|c|c|c|}
\hline Nos últimos dois anos, você visitou: & MZ & MP & Pina \\
\hline MP/MZ/MP & $21,1 \%$ & $5,7 \%$ & $9,4 \%$ \\
\hline Museu Instituto Butantan & $10,6 \%$ & $9,9 \%$ & $4,9 \%$ \\
\hline Museu Lasar Segall & $1,8 \%$ & $2 \%$ & $3,8 \%$ \\
\hline Pina/Pina/MZ & $8,4 \%$ & $10 \%$ & $2,3 \%$ \\
\hline Centro Cultural São Paulo (CCSP) & $6,8 \%$ & $7,7 \%$ & $13 \%$ \\
\hline Zoológico de São Paulo & $20,2 \%$ & $19 \%$ & $6,6 \%$ \\
\hline Museu de Arte de S.Paulo (Masp) & $10,8 \%$ & $15,3 \%$ & $21,1 \%$ \\
\hline Estação Ciência & $3,5 \%$ & $2,2 \%$ & $2,6 \%$ \\
\hline Museu de Arte Moderna (MAM) & $5,3 \%$ & $8,5 \%$ & $15,2 \%$ \\
\hline $\begin{array}{l}\text { Museu de Arte Contemporânea } \\
\text { (MAC/USP) }\end{array}$ & $2 \%$ & $2,5 \%$ & $7,3 \%$ \\
\hline Memorial Imigrante & $5,9 \%$ & $4,2 \%$ & $5 \%$ \\
\hline Outros museus/SP & $2 \%$ & $2,2 \%$ & $5,7 \%$ \\
\hline Não respondeu & $1,8 \%$ & $11 \%$ & $3 \%$ \\
\hline Total & $100 \%$ & $100 \%$ & $100 \%$ \\
\hline
\end{tabular}

Para os respondentes do MP, o Zoológico e o Museu de Arte de São Paulo (Masp) aparecem com os maiores índices. $\bigcirc$ mesmo ocorre aos visitantes do $M Z$, nesse caso incluindo o próprio MP como o mais visitado. Entre os "outros" citados pelos respondentes do MP, aparecem o Memorial da América Latina, Museu de Arte Sacra e Museu da Imagem e do Som, mas todos com poucas citações (máximo cinco ocorrências).

Já os respondentes da Pinacoteca, além de indicarem em maior índice - Masp, o Centro Cultural São Paulo (CCSP) e o Museu de Arte Moderna (MAM), entre os "outros" indicam maior variedade de museus, mas sempre em freqüência superior àqueles que têm a arte como tema principal: Museu de Arte Brasileira/Faap, Museu de Arte Sacra, Itaú Cultural, Memorial da América Latina, Bienal, Museu Brasileiro de Escultura, entre outros. 
Verificou-se que o público do Museu Paulista freqüentou em média menos museus em dois anos do que os públicos da Pinacoteca e do Museu de Zoologia. Apesar de não existir diferença significativa entre o público destes dois últimos em relação ao número de locais visitados, existe uma clara evidência de que a média de visitas a museus (em dois anos) do público da Pinacoteca é um pouco maior e assume valores mais altos do que a do público do Museu de Zoologia.

Mas Falk e Dierking chamam atenção para o fato de que é preciso interpretar os dados com cuidado:

[... the data would be better interpreted to suggest who does not visit art museums, rather than who does visit zoos. The fact is that the number of people in high socioeconomic brackets visiting zoos and art museums may be comparable (some may even be the same people), because a relatively constant number of people in high socioeconomic brackets attend all museum settings.

The difference in 'average' socioeconomic status between visitors to art museums and visitors to zoos is more highly correlated with the popularity of the museum than with the status of the visitor; it is more a function of how many visitors from the moderate and low socioeconomic segments of the population are attracted, then of how many upper-income people visit (FALK; DIERKING, 1992, p. 221.

De acordo com as colocações acima, não seria então surpreendente encontrar visitantes de alta renda nos três museus, mas especialmente na Pinacoteca, como veremos a seguir.

Escolaridade e renda

No Brasil não temos pesquisas amplas como as realizadas na Europa, nos EUA, Canadá ou México (SCHUSTER, 1992; LINTON et al., 1992; LEHALLE; MIRONER, 1993; CIMET et al., 1987; CLARK et al., 1985; DIGBY, 1973; DOERING; BICKFORD, 1997), mas mesmo que parcialmente, pesquisas brasileiras têm indicado resultados semelhantes quanto à influência da escolaridade e da renda na freqüência a museus (ALMEIDA, 2001; ROCHA; MOUTINHO, 1997; PINACOTECA DO ESTADO, 2002).

Em pesquisa realizada em quatro museus da Smithsonian Institution (Washington, D.C.), ficou evidente que o National Air and Space Museum (Nasm) e o National Museum of Natural History (NMNH) atraíam mais famílias com crianças, enquanto a Freer Gallery of Art e Arthur M. Sackler Gallery (FreerSackler) recebiam mais visitantes adultos sozinhos ou casais. A pesquisa também identificou tipos de visitantes segundo a imagem criada pelos museus:

In addition, each museum seems to have its own image in the minds of visitors and thus attracts a particular audience out of the general flow of Mall visitors. The data suggests that a NASM visit is seen as general and subject-based and especially attractive to men. On the other hand, a NMNH visit tends to be directed to specific agendas and particularly draws 
children. A Freer-Sackler visit is closely associated with very high levels of formal education and a relatively private experience among adults.

Compared to these other museums, NMAH [National Museum of American History] has a less distinctive audience. This suggests the possibility that its image in the minds of visitors may not be as well formed as that of the other museums on the Mall (DOERING; BICKFORD, 1997, p. 14).

Infelizmente não há detalhes no texto que expliquem porque o National Museum of American History não teria conseguido formar uma imagem tão

\begin{tabular}{|l|c|c|c|}
\hline Escolaridade & MZ & MP & Pina \\
\hline Fundamental incompleto & $1,8 \%$ & $4,5 \%$ & $1,2 \%$ \\
\hline Fundamental completo & $8,3 \%$ & $8,8 \%$ & $3,4 \%$ \\
\hline Médio completo/incompleto & $18,3 \%$ & $24,9 \%$ & $13,8 \%$ \\
\hline Superior completo/incompleto & $58 \%$ & $46,8 \%$ & $56,4 \%$ \\
\hline Pós-graduação & $11,8 \%$ & $12,4 \%$ & $24,5 \%$ \\
\hline Outros & $1,2 \%$ & $0,4 \%$ & $0,4 \%$ \\
\hline Não respondeu & $0,6 \%$ & $2,1 \%$ & $0,3 \%$ \\
\hline Total & $100 \%$ & $100 \%$ & $100 \%$ \\
\hline
\end{tabular}

\begin{tabular}{|l|c|c|c|}
\hline Renda familiar & $M Z$ & $M P$ & Pina \\
\hline Até $R \$ 400,00$ (dois salários mínimos) & $4,1 \%$ & $5,8 \%$ & $2,5 \%$ \\
\hline$R \$ 401,00$ a $R \$ 800,00$ & $5,3 \%$ & $11,4 \%$ & $5,8 \%$ \\
\hline$R \$ 801,00$ a $R \$ 2.000,00$ & $27,8 \%$ & $25,1 \%$ & $21,8 \%$ \\
\hline R\$ $2.001,00$ a $R \$ 4.000,00$ & $32 \%$ & $23,6 \%$ & $27 \%$ \\
\hline Mais de $R \$ 4.001,00$ & $24,9 \%$ & $22,5 \%$ & $36,5 \%$ \\
\hline Outros & $2,4 \%$ & $3 \%$ & $1,9 \%$ \\
\hline Não respondeu & $3,6 \%$ & $8,6 \%$ & $4,5 \%$ \\
\hline Total & $100 \%$ & $100 \%$ & $100 \%$ \\
\hline
\end{tabular}


definida para o público quanto os outros museus citados. Apesar das diferenças dos públicos desses museus, outras pesquisas realizadas pela Smithsonian Institution têm revelado que, entre os norte-americanos, os freqüentadores das instituições culturais costumam ser os mesmos. Ao perguntar por telefone, para pessoas de mais de 18 anos, que tipo de instituições culturais haviam visitado no ano anterior, obteve-se as seguintes generalizações:

The study shows that 44 million adults, almost one-fourth of the population of 185 million, visited only one institution...

\begin{tabular}{|c|c|}
\hline & Millions \\
\hline Natural History museums & 0.5 \\
\hline Science and technology centers & .3 .1 \\
\hline 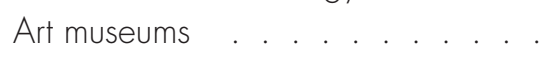 & 4.5 \\
\hline History museums and Historical sites & .12 .6 \\
\hline Zoos and Aquaria . . . . . . . . & \\
\hline
\end{tabular}

About 72 million people $(31,9 \%)$ attended 2,3 or 4 types of institutions Another 6 million visited every type of institution at least once (DOERING, 1995, p. 91.

Entre as instituições visitadas isoladamente, destacam-se os museus e sítios históricos em segundo lugar, mostrando o interesse gerado pela temática histórica entre os norte-americanos. Outra tendência revelada, ou melhor, confirmada, foi a influência da escolaridade na freqüência a instituições culturais: o número de visitas a museus aumenta proporcionalmente à escolaridade. Outro fator relevante é a renda, apesar de ser menos significante que a escolaridade: conforme aumenta a renda também aumenta a freqüência de visitação a instituições culturais (DOERING, 1995).

Todas as pesquisas de perfil de público de museus evidenciam a alta escolaridade como característica dos visitantes. Assim, todos os tipos de museus recebem visitas de pessoas com nível superior (graduação e pós-graduação) e só alguns atraem o público menos escolarizado, geralmente zoológicos, centros de ciências e parques. Fenômeno análogo se dá em relação à renda e ao padrão socioeconômico.

Os resultados desses levantamentos mais amplos têm sido discutidos e novas pesquisas têm apresentado detalhamentos. Na prática, eles mostram que as instituições culturais partilham os mesmos públicos e portanto deveriam realizar ações conjuntas para manter os atuais públicos e atrair novos.

Richard Prentice e colegas fizeram um estudo em Edimburgo, Escócia, entre os residentes que circulavam na região central da cidade, onde se localizam as principais atrações culturais, identificando as razões para ir a museus e outras opções culturais da cidade. Para aqueles que tinham visitado um museu nos 12 meses precedentes, solicitou-se que indicassem as razões que os levaram à visita e para aqueles que não tinham visitado (não-visitantes), pediu-se que 
selecionassem os motivos para tal. Como em outras pesquisas, os mais escolarizados e com melhor renda freqüentavam mais museus e outras atividades culturais. Entretanto, o perfil sociodemográfico não se mostrou determinante das motivações para a visita. Na maior parte das vezes, as razões são múltiplas, variando entre "ganhar conhecimento genérico", "por curiosidade", "sair da rotina", "relaxar com parentes e amigos" e outras (PRENTICE, 1997, p. 53). Apenas a idade apareceu como elemento diferencial das razões para ir a museus. Por exemplo, os visitantes com mais de 50 anos deram como razão da visita a busca de conforto, a fuga da rotina e o interesse específico com muito mais freqüência do que os jovens, com menos de 31 anos (Prentice, 1997, p. 55).

Esses resultados indicam que é preciso utilizar com cuidado as generalizações e tratar de forma mais isolada o perfil sociodemográfico das motivações para a visita.

Na pesquisa realizada no Museu Lasar Segall (MLS), encontramos um público altamente escolarizado $179 \%$ de nível superior - graduação e pósgraduação), freqüentador de museus de arte (61\% visitam mais de quatro vezes por anol e muitas vezes praticante de atividades artísticas, profissional ou amadoristicamente, ou seja, um público de "iniciados" na área.

Quando cruzamos as informações sobre o hábito de visitar museus de arte com o número de visitas ao MLS, confirmou-se que aqueles que já haviam visitado o MLS mais vezes freqüentavam mais museus de arte em geral. Assim, daqueles visitantes que estavam pela primeira ou segunda vez no MLS, 57\% e $51 \%$ costumavam visitar museus mais de quatro vezes ao ano, respectivamente. Daqueles que estavam pela terceira, quarta ou mais vezes, a freqüência foi de $66 \%, 75 \%$ e $85 \%$, respectivamente (ALMEIDA, 2001 ).

Esses resultados demonstram que as pessoas que costumam visitar um museu de arte são freqüentadores de outros museus e exposições de arte, ou seja, as mesmas pessoas compõem os públicos das várias exposições de arte da cidade.

Um estudo de hábitos de consumo cultural realizado na cidade de Belo Horizonte (MG), na década de 1990, elaborado a partir de 720 entrevistas com moradores de 15 a 50 anos e de seis grupos de discussão com consumidores culturais de 15 a 45 anos, registrou uma maior freqüência desses a shows, espetáculos musicais (37\% foram de uma a cinco vezes ao ano) e cinemas (32\%) do que a teatro (25\%), espetáculos de dança (17\% de uma a cinco vezes ao anol e museus. No caso dos museus, $41 \%$ declararam nunca ter ido a um museu em Belo Horizonte, 18\% foram apenas uma vez e 33,2\% foram algumas vezes. relatório evidenciou que "quanto maior a renda, maior a incidência de consumo [cultural] em todos os itens pesquisados, independente do local onde [o indivíduo] reside, sexo ou faixa etária" ISECRETARIA MUNICIPAL DE CULTURA, 1996, p. 70). Os dados também reafirmaram que "quanto mais baixo o nível de instrução, menor a presença de consumidores de produtos culturais" (SECRETARIA MUNICIPAL DE CULTURA, 1996, p. 34). 
Nos três museus pesquisados, identifiquei públicos altamente escolarizados e também com renda alta, se comparados à população em geral. Ao cruzar a escolaridade com o número de museus visitados anualmente, confirmase a tendência de mais visitas para quem tem maior escolaridade.

Museu Paulista

Visitas a museus $\times$ Escolaridade

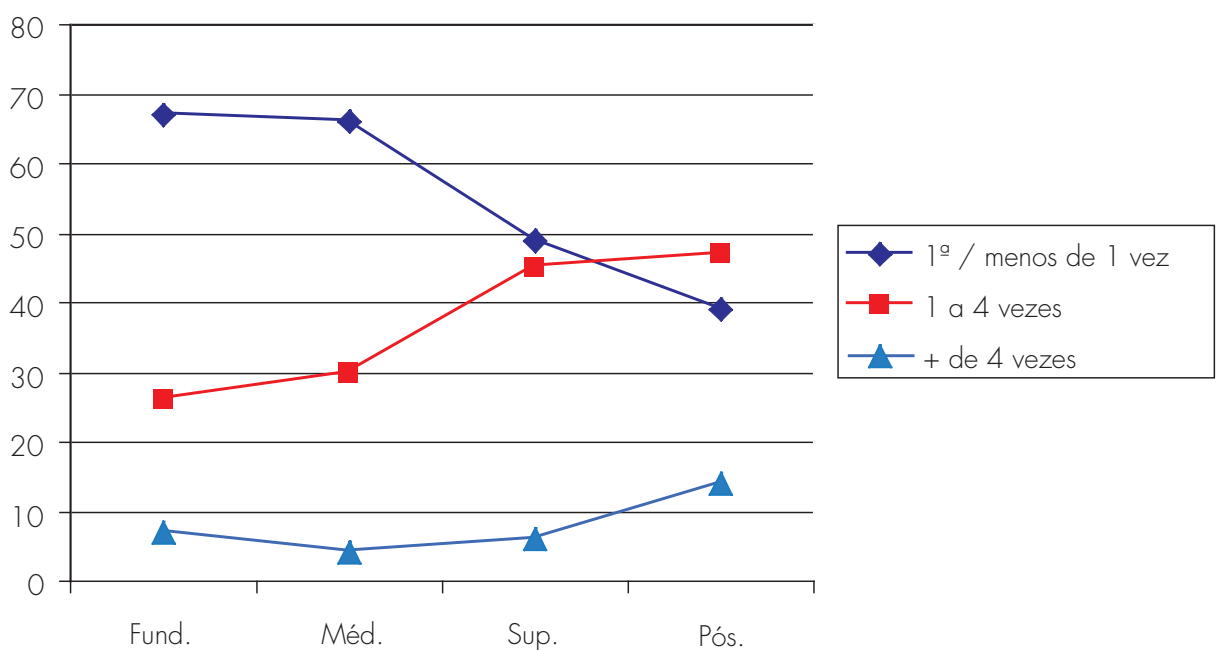

No geral, para os três museus, conforme aumenta a escolaridade decresce a opção "primeira vez ou menos de uma vez por ano" e cresce a categoria "mais de quatro vezes por ano". Nesta última categoria, os percentuais da Pinacoteca são sempre superiores, seja qual for o nível de escolaridade, enquanto os do Museu de Zoologia e do Museu Paulista são menores e semelhantes.

Nas respostas à questão sobre os museus visitados nos últimos dois anos, também há a tendência de um maior número de museus visitados conforme aumenta a escolaridade: os respondentes de nível fundamental do Museu de Zoologia, Museu Paulista e Pinacoteca visitaram em média 1,80; 2, 14 e 2,33 museus enquanto os respondentes de pós-graduação visitaram 3,53; 3,34 e 3,68 , respectivamente.

Pelos dados até agora apresentados evidencia-se que o Museu Paulista teve um grupo de respondentes com escolaridade e renda um pouco inferior às dos outros dois museus e também um público que freqüenta menos museus, teatros e outras atividades culturais. Estando praticamente ao lado do Museu de Zoologia, recebe um número cinco vezes maior de visitantes e de perfil demográfico mais heterogêneo ${ }^{26}$ do que aquele. Entretanto, ainda assim tem grande parte do público visitante com alta escolarização e renda se comparado à população em geral.

Nick Merriman (1989) fez uma análise de dados levantados em diferentes pesquisas entre a população da Grã-Bretanha, procurando verificar o
26. Cecília Helena S. Oliveira realizou mais de 40 entrevistas com visitantes do Museu Paulista entre 1992 e 1995 e observou a "diversidade do público visitante", residentes em diversos bairros e cidade e de diferentes "segmentos sociais"(OLIVEIRA, 2003, p. 118) 
interesse por História e por museus históricos, entre os respondentes. Para o autor, as pessoas tinham interesse em História - seja familiar, local, regional, nacional, mundial - com diversos pesos e diferentes formas de responder a isso. Algumas pessoas preferiam assistir a um programa de TV ou visitar um sítio histórico, enquanto outros preferiam ler um livro sobre o assunto. As pessoas de menor escolaridade e renda costumavam ter maior interesse pela história pessoal e local e ir menos a museus e sítios históricos do que as mais escolarizadas e de maior renda que tinham interesse maior na História mundial e nacional e valorizavam museus e sítios históricos.

[...] part of the explanation for museum visiting patterns lies in the fact that museums still have the legacy of an elitist high culture image that certain groups find intimidating, and partly in the fact that some people participate in a much wider range of activities in their leisure time than others (MERRIMAN, 1989, p. 159).

Merriman (1989), citando Bourdieu, chama atenção para a questão do "habitus", cultivado pela família, pela escola e pelo ambiente social no qual o indivíduo convive, que pode dar os códigos para a compreensão de uma obra de arte, de um museu, e, portanto, fornecer o "capital cultural" para valorizálos. Nesse sentido, o patrimônio ("heritage") é valorizado pelos grupos que possuem competência para compreendê-lo e o hábito de visitar museus e monumentos históricos é tão estimulado quanto ir ao teatro, reforçando um estilo de vida e a filiação a determinado grupo social.

Em pesquisa realizada na Alemanha, em 1995, verificou-se que 1/3 da população vai regularmente a museus e $2 / 3$ vai com pouca freqüência ou não vai. Os respondentes não teriam uma rejeição a museus "por princípio", mas sim porque mantêm uma imagem ultrapassada deles como "templo das musas" - local de contemplação sem comunicação.

The popular image of museums is still that of the classic art museum that typically addresses a target population with an above-average level of education and income, as empirical studies show. (DENNERT, 2001).

Na Alemanha, numa onda de interesse por História na década de 1990, os museus históricos se colocaram entre as diversas mídias que proporcionam informações históricas - livros, documentários de TV, CD-ROMs, etc. - entretanto apareceram em nono lugar numa pesquisa de opinião quando os alemães responderam como preferiam buscar informações históricas. A televisão apareceu em primeiro lugar (SCHÄFER et al., 2001).

Ainda não temos levantamentos ("surveys") desse porte no Brasil, mas pelas respostas obtidas nas pesquisas entre os visitantes do Museu Paulista, fica claro que, ao visitar o museu há a expectativa de aprender História, de aproximarse do passado, seja de uma forma emocional e sacralizadora, seja com uma abordagem mais cognitiva e objetiva.

Museu Paulista era um museu de história natural que ocupou um monumento construído para celebrar a Independência do Brasil. Seu primeiro 
diretor, o zoólogo Hermann von lhering, desenvolveu principalmente as coleções e exposições de História natural, relegando a História a um segundo plano. Na gestão de Affonso d'Escragnolle Taunay (1917-1945), o museu tomou o perfil de museu histórico e se afastou das ciências naturais:

Sem dúvida alguma, Taunay tinha consciência de que, apesar do Museu ter iniciado suas atividades como um museu de história natural, ele fora pensado como um depositário e um tabernáculo de "objetos históricos" - sobretudo retratos e estátuas que rememorassem os grandes homens e os grandes feitos referentes à constituição da pátria brasileira - e, neste caso, seria um lugar privilegiado para a celebração e perpetuação da memória nacional (BREFE, 2003, p. 86-87).

E em seu projeto, apoiado pela elite de São Paulo, haveria um destaque para a história paulista no contexto nacional. Por meio de pinturas, esculturas, elementos decorativos e objetos, Taunay transformou a iconografia e exposições das salas do museu numa narrativa histórica

contada de maneira encadeada como uma celebração de fatos significantes, realizados por homens memoráveis. $\bigcirc$ desfilar de inúmeras alegorias históricas, sabiamente dispostas e articuladas no espaço, salienta o papel de São Paulo como um lugar material e simbólico da Independência nacional (BREFE, 2003, p. 101).

Durante a gestão de Taunay e nas décadas posteriores muitas modificações foram feitas nas exposições ${ }^{27}$. Entretanto, grande parte dos elementos iconográficos inseridos na decoração do prédio permaneceram em seus locais originais.

A fala dos visitantes

Nessa parte farei uma primeira leitura das respostas às questões abertas. Para uma interpretação mais completa precisarei realizar novas entrevistas, que poderão me fornecer pistas mais claras sobre o sentido das palavras colocadas pelos visitantes.

Assim, nas respostas dos visitantes a "história" aparece em destaque quando indicam os benefícios da visita, entretanto o significado de história para cada um deles possivelmente não é o mesmo.

Os respondentes do Museu Paulista indicaram com maior freqüência os benefícios educacionais seguidos dos culturais (ver tabela na p. 280). Ao procurar entender o que o visitante teria aprendido/conhecido, encontrei diferentes conteúdos, relacionados principalmente à História. Citarei a seguir, algumas respostas escritas pelos visitantes, de acordo com os seus conteúdos, para conhecer mais profundamente a sua experiência no museu ${ }^{28}$.

A História aparece em sentido mais geral, ou do Brasil ou de São Paulo, com mais referência à História naciona ${ }^{29}$. Nessas falas repetem-se os verbos
27. Inclusive a saída definitiva das coleções de Ciências naturais em 1939 e as de Etnologia e Arqueologia a partir de 1989.

28. Não incluiremos aqui respostas genéricas como "aprimorar conhecimentos", "conhecimentos gerais" ou "aprendizado", pois não têm um conteúdo identificável.

29. Nessa categoria houve 51 citações da História geral, 80 da nacional e 14 de São Paulo. 
30. Outros exemplos das falas dos visitantes:"conhecer/conhecimento (d)a nossa história”; "ajudam a gente a entender melhor a história do nosso Brasil"; "conhecer um pouco sobre a história do Brasil e da independência";"conhecimentos adquiridos da história dos nossos antepassados";"adquirir conhecimento da história/costume do país"; "adquirir cultura"; "conhecer e reviver a nossa história e cultura", "aprimorar os conhecimentos da história do Brasil"; "saber um pouco mais sobre os personagens da história do Brasil"; "rever história do Brasil","lembrar da cultura e história do país"; "conhecer a história/conhecimento histórico"; "conhecer melhor os tempos antigos. Eu acho fascinante"; "enriquece o conhecimento na área de história, entre outros"; "reconhecer a arte histórica", "aprimorar o conhecimento sobre a nossa cidade", "um breve passeio pela história, recapitulação de conhecimentos e aprimoramento de fatos históricos da região do museu", "conhecimento/conhecer (d)a história da cidade", "preciso saber o que aconteceu no passado, pois re sido próxima(sic)","chegar a saber das epidemias aqui em SP no século 19".

31. Nessa categoria houve 16 citações.

32. Outros exemplos nessa categoria: "valorização do passado, realização no presente e esperança no futuro"; "aprimorar o alicerce histórico e cultural meu, de familiares e ami gos com transmissão de conhecimento adquirido";"aprender um pouco mais sobre a história, despertar curiosidade nas crianças";"eu não esperava ter um impacto cultu- "conhecer/aprender/adquirir" ou "aumentar" ou "reconhecer/rever", valorizando - Museu Paulista como espaço pedagógico, no qual se pode "conhecer mais a história de nosso país", "aprender sobre os costumes dos séculos anteriores/evolução da sociedade" ou "adquirir conhecimentos da história dos povos" 30 .

A História também aparece como algo "útil" a se conhecer ${ }^{31}$, com funções ligadas à preservação "conhecer a história para poder melhor preservála", à formação das crianças "conhecer mais sobre a história do Brasil e orientar melhor minha filha" e à possibilidade de um futuro melhor "conhecer a história, para entender e viver melhor o futuro e o presente" ${ }^{\prime \prime 2}$.

Outra função de conhecer a História seria referente à formação da identidade ${ }^{33}$, mesmo que expressa de forma muito genérica: "compreensão da nossa história: identidade" ou "você fica integrado ao passado do seu país, aprendendo sobre a história e seus personagens".

Diferentemente da pesquisa de Cecília Helena S. Oliveira, na qual a Independência aparece como assunto principal da fala dos respondentes, realizada por meio de entrevistas nas quais perguntava em específico sobre "o significado da Independência e das comemorações de 7 de setembro; as peças em exposição mais representativas da Independência e a importância do Museu Paulista em relação à Independência" (OLIVEIRA, 2003, p. 1 16), na minha pesquisa, apenas um respondente fez referência explícita à Independência, na resposta sobre benefícios da visita: "conhecer um pouco sobre a história do Brasil e da Independência". Entretanto, várias outras respostas apontam para o Museu Paulista como um memorial da pátria, um símbolo nacional a ser cultuado ${ }^{34}$ : "noções de patriotismo e civilidade às crianças principalmente" ou "conhecer nossas raízes, orgulho de ser brasileiro" ${ }^{\prime \prime 2}$.

Outra categoria de respostas que envolveu "história" diz respeito à possibilidade de aproximação concreta com o passado por meio dos objetos expostos. Para alguns visitantes, o museu permite "ver de perto" e ter contato com o passado, causando inclusive um sentimento de nostalgia, de idealização do passado 36: "concretizar nomes, fatos e objetos da história brasileira citados em estudos"; "ver de perto a história" ou "lembrar ou conhecer pouco de uma época que gostaríamos de ter vivido" ${ }^{37}$.

Alguns autores criticam as exposições históricas que reconstituem ambientes, por tentar presentificar algo que não pode mais ser vivido, pois já passou e cada reconstituição é na verdade uma nova construção dos eventos do passado, uma nova leitura que não pode se impor como "verdade". Ulpiano B. de Meneses aponta alguns perigos da "recontextualização" em museus históricos: primeiro, o congelamento do objeto num contexto único, quando ele tem várias trajetórias; segundo, ignora-se que o objeto transformado em documento "introduz referências a outros espaços, tempos e significados numa contemporaneidade que é a do museu, da exposição e de seu usuário" (MENESES, 1994a, p. 32); e em terceiro, a reprodução de contextos "mascara as articulações invisíveis", fazendo que a exposição não exija um "esforço crítico e criativo" do visitante (MENESES, 1994, p. 32). 
Outros benefícios são indicados nas outras categorias lque não "educacional" ou "cultural") e por vezes o termo história aparece de maneira muito genérica. Apenas um visitante, criticou as exposições de forma bastante contundente: "Infelizmente nenhum [benefício], não há cronologia nem material de áudio sobre a história do Brasil, as peças estão malconservadas."

Para dar uma visão sintética das preferências dos respondentes, elencamos as palavras que se repetem cinco ou mais vezes nas respostas à questão sobre os benefícios da visita. A freqüência da palavra "conhecer" demonstra que os respondentes vêem no museu um espaço para aprendizagem, e o conteúdo "histórico" indica o reconhecimento do Museu Paulista como uma fonte para o "conhecimento histórico".

\begin{tabular}{|l|c|}
\hline Palavras citadas cinco ou mais vezes - Benefícios & $f$ \\
\hline Conhecimento/conhecer & 219 \\
\hline História/histórico & 168 \\
\hline Cultura/cultural & 119 \\
\hline Brasil/país/nacional & 76 \\
\hline Passado/passadals) & 32 \\
\hline Aprender/aprendizagem & 16 \\
\hline Enriquecimento/enriquecer & 14 \\
\hline Lazer/passeio & 13 \\
\hline Antigo/antigüidade & 9 \\
\hline Ampliar/aumento & 8 \\
\hline Filhos/crianças & 6 \\
\hline Arte & 5 \\
\hline Futuro & 5 \\
\hline Total & 690 \\
\hline
\end{tabular}

Nas respostas ao que mais gostaram também podemos encontrar alguns conteúdos ligados à História e a outros temas, como a arte, o cotidiano, a arquitetura do prédio, etc. ${ }^{38}$. ral tão grande, me conscientizando a ter um maior respeito e interesse pelo passado"; "conhecimento histórico e passeio (lazer)";"conhecer a história do país, usufruir do ambiente agradável".

33. Nessa categoria houve três citações.

34. Nessa categoria houve 12 citações.

35. Outros exemplos:"para mim é como se eu estivesse indo ao passado, e os seus benefícios são dar valores a nossa história, cultura é ensinar aos nossos filhos amar a nossa Pátria (sic)";"contribui para o fortalecimento da nossa mente patriótica"; "retroagir na história da ascendência nacional e transcender com enge nho e garbo a memória e os fatos do nosso merífico (sic) país".

36. Houve 28 citações nessa categoria.

37. Outros exemplos:"conhecer casas e objetos antigos e saber um pouco de nossa história”;"conhecer a história mais de perto"; "a história se torna uma coisa mais próxima, vê-se que ela faz parte da nossa vida"; "entrar em contato com o passado por meio de exposições de objetos e documentos"; "vivenciar a história”;"adquirir conhecimento. Sensação de nostalgia"; "conhecer sobre nossa história, sobre nosso povo. O museu nos leva ao passado, nos faz reviver, apesar de nunca ter vivido isto", "reviver a história através de objetos, quadros da época".

38. Não estarão incluídas aqui as respostas genéricas como "tudo", "museu como um todo", "aparência". 
39. Houve 74 citações nessa categoria.

40. Outros exemplos "hall de entrada, história de SP, maquete do museu"; "arquitetura e quadros tristes"; "jardim, escadaria, quadro da Independência"; "escadaria objetos de construção, porta chapéus"; "anda por uma construção tão antiga e imaginar como as pessoas viviam antigamente"; "maquete de São Paulo"; "maquete do museu"; "maquetes"; "é importante ressaltar a exuberância das maquetes, tanto da cidade de SP como do Museu"; "a representação dos rios com sua água".

41. Alda Heizer (1994) fez uma interessante leitura do Museu Imperial de Petrópolis como uma casa de "família exemplar", criado nos moldes dos ideais educacionais e culturais da Era Vargas. $\mathrm{O}$ prédio do museu foi residência de verão da famí lia imperial, porém a maior parte do mobiliário e do acervo não estava originalmente naque le local.

42. Três respondentes manifestaram explicitamente o benefício da vi sita como sendo a possibilidade de "visualizar o que está em fotos de livros".

\begin{tabular}{|l|c|c|}
\hline Do que você mais gostou de sua visita ao Museu Paulista? & $f$ & $\%$ \\
\hline Tudo/conjuntos genéricos & 145 & $26,6 \%$ \\
\hline Obra/objeto específico/autor específico & 54 & $9,9 \%$ \\
\hline Museografia/organização exposição & 16 & $2,9 \%$ \\
\hline Exposição específica/módulo específico/sala esp. & 139 & $25,5 \%$ \\
\hline Textos/vídeos/outras mídias & 4 & $0,7 \%$ \\
\hline Outros & 61 & $11,2 \%$ \\
\hline Arquitetura/prédio & 56 & $10,3 \%$ \\
\hline Não respondeu & 71 & $13,0 \%$ \\
\hline Total & 546 & $100 \%$ \\
\hline
\end{tabular}

Há uma clara preferência pela arquitetura do prédio e outros elementos arquitetônicos, assim como as maquetes da cidade e do museu, reforçando o valor dado ao prédio como monumento e elemento de atração dos visitantes ${ }^{39}$ : "arquitetura e dos (sic) detalhes da decoração"; "arquitetura do prédio, do parque e da maquete da cidade de São Paulo" ou "quarto da princesa"40.

A preferência pelo prédio, por sua decoração e pela representação por meio de maquete, indica o impacto positivo causado pela construção monumental e representativa da celebração da História do Brasil. Os visitantes gostam de caminhar pelos amplos espaços do museu. Alguns têm prazer em conhecer a intimidade da casa da família imperial porque acreditam estar num edifício que teria sido residência imperia ${ }^{41}$.

Várias respostas referiam-se a objetos ou conjuntos de objetos. As obras de arte, como citado anteriormente, aparecem entre os objetos bastante apreciados, especialmente a tela Independência ou Morte!, de Pedro Américo. Essa tela, por seu tamanho $(7,60 \times 4,15 \mathrm{~m})$, por seu local de destaque no Salão Nobre, pela temática totalmente relacionada à Independência, ou seja, bastante identificada com o prédio como monumento, e por sua enorme divulgação na mídia e nos livros didáticos ${ }^{42}$, é um dos objetos mais conhecidos do museu, por aqueles que já foram lá e por aqueles que nunca a viram ao vivo. Assim, a sua citação como objeto preferencial pode também estar relacionada ao fato de ser um dos objetos mais fáceis de se reconhecer e se identificar com o próprio museu. O mesmo ocorre com o Salão Nobre citado por vários respondentes como sua preferência na visita. As telas do Salão Nobre foram especialmente confeccionadas para ocupar suas paredes, sendo que Independência ou Morte! 
foi encomendada para fazer parte do monumento logo que foi construído e as outras encomendadas por Taunay até $1922^{43}$.

Os veículos (automóveis, carruagens, etc.), as armas, as peças de indumentária (roupas e chapéus) e os objetos de porcelana também ficaram entre os preferidos dos respondentes. Enquanto a indumentária e as louças foram significativamente mais apreciadas pelas mulheres ${ }^{44}$, os veículos foram preferidos pelos homens. As armas, geralmente consideradas de maior interesse masculino, foram apreciadas igualmente por visitantes do sexo masculino e feminino. Esses resultados indicam a necessidade de aprofundarmos a questão das preferências em relação a gêneros, uma vez que os resultados indicam diferenças, mas não as explicam ${ }^{45}$.

Nas respostas ao que mais gostaram, a história aparece ligada a vários conteúdos das exposições. A "Independência" aparece várias vezes entre esses conteúdos: "ver antigüidades relacionadas não só à Independência, mas à cidade de São Paulo"; "história da Independência" ou "parte histórica da cidade de São Paulo" 46 .

Apesar do Museu Paulista não oferecer serviços básicos aos visitantes - banheiro interno, café, bebedouros - parte dos respondentes apreciou sua organização e limpeza. Esses mesmos serviços foram solicitados com maior freqüência quando os visitantes fizeram suas reclamações e sugestões ${ }^{47}$.

Apresento a seguir uma lista das palavras citadas cinco ou mais vezes nas respostas sobre o que mais gostaram na visita ao Museu Paulista. Há uma preferência para as pinturas, o prédio, as telas e os objetos, sendo que "história" e "Independência" também aparecem com freqüência (ver tabela na p. 298).

Nas respostas ao que sentiram falta ou quais sugestões gostariam de dar, os visitantes, além de solicitar os serviços básicos, pediram mais objetos em exposição e mais informações. Entretanto, a maior parte dos respondentes (52,5\%) não tinha sugestões a dar, quando perguntada sobre o que sentiu falta. Isso indica que ficaram satisfeitos com o que o Museu Paulista thes ofereceu no dia da visita.

Aqueles que fizeram sugestões indicaram, entre as respostas mais freqüentes, um maior número de objetos e/ou exposições (12\%), melhorar infraestrutura $(9,5 \%)$ e acompanhamento de guia/especialista $(6,8 \%)$ (ver tabela na p. 299).

Objetos da família real/imperial "pertences/mais conteúdo sobre a família real", peças de indumentária "roupas de época, vestidos de festa, acessórios femininos", principalmente femininas e veículos "carros, objetos da família de D. Pedro, roupas", são os conjuntos de objetos mais solicitados pelos respondentes ${ }^{48}$.

Alguns visitantes solicitaram "cenários reproduzindo a época, com manequins e figurantes" ou a possibilidade de "ver o quarto do rei", como já comentado quando tratei da preferência pelo prédio. Novamente, aparece indicação de que os visitantes acreditam que o prédio foi moradia da família imperial e o desejo de conhecer sua "intimidade", sua casa.
43. MENESES, 1992c.

44. Teresa Toledo de Paula (2004) afirma que "os tecidos foram sempre associados ao corpo e ao gênero feminino" (p. 97) e que no Museu Paulista, "por muitas décadas predominaram os acervos masculinos, os tecidos masculinos, indumentária ou não, como uniformes, as bandeiras e demais objetos relacionados com as atividades nas guerras, batalhas e revoluções, independentemente de sua procedência." (p. 107) Mas, posteriormente, houve um crescimento da coleção de têxteis (em estimativa do ano 2000 teria sido de $170 \%$, agora "predominantemente feminina". (p. 108). Essas considerações reafirmam a necessidade de novos estudos da experiência no museu do ponto de vista do sexo do visitante e daquilo que a exposição apresenta.

45. Das 42 respostas que incluíram "veículos" como preferência, 24 foram dadas por visitantes do sexo masculino e 18 do feminino. No caso das "armas" foram 15 masculino e 15 feminino. Para a indumentária foram $20 \mathrm{fe}$ minino e 10 masculino, $\mathrm{e}$ para as louças, 16 feminino e quatro masculino.

46. Outros exemplos:"impossível descrever algo específico, pois tudo (sic) trata-se de um complexo histórias enriquecedora de conhecimentos"; "trazer as pessoas que ainda não tinham visto o acervo de peças da nossa história".

47. Houve 22 citações da organização e limpeza como o que mais gostaram e 46 citações solici- 
tando banheiros internos, lixeiras, lanchonetes entre outros serviços.

48. Outros exemplos nessa categoria:"coroa de D. Pedro"; "trono de D. Pedro, da Coroa, da pia batismal de D. Pedro"; "roupas e vestidos de princesas"; "senti falta das roupas de época femininos e uniformes masculinos e uma ala para nossas revoluções e hospitais (cenários)". Não citarei as respostas genéricas, $\mathrm{co}^{-}$ mo "mais exposições" ou "mais obras".

\begin{tabular}{|c|c|}
\hline Palavras citadas cinco ou mais vezes - mais gostaram & $f$ \\
\hline Tudo & 92 \\
\hline Quadros/telas/pinturas & 55 \\
\hline Arquitetura/prédio & 51 \\
\hline Carros/automóveis/veículos/carruagens/transporte & 42 \\
\hline Armas & 30 \\
\hline Maquete(s) & 30 \\
\hline Roupas/vestimentas/chapéus & 30 \\
\hline Antigo/antigüidade/antigamente & 27 \\
\hline Museu & 24 \\
\hline Porcelanas/louças & 20 \\
\hline Objetos/acervo & 20 \\
\hline História/histórico & 19 \\
\hline Conhecer/conhecimento & 14 \\
\hline Móveis/mobiliário & 14 \\
\hline Organização/limpeza & 14 \\
\hline Foto(s) & 13 \\
\hline Independência & 13 \\
\hline Salão & 13 \\
\hline Arte & 12 \\
\hline Sala(s) & 9 \\
\hline Escada/escadaria & 8 \\
\hline Estrutura & 6 \\
\hline Pedro Américo & 5 \\
\hline Escultura(s) & 5 \\
\hline Utensílio(s) & 5 \\
\hline Total & 573 \\
\hline
\end{tabular}


"Indicação dos cômodos que eram utilizados na época", ou o cenário com "bonecos de cera dos principais membros da história", do ponto de vista desses visitantes, poderiam informar mais claramente como "realmente" vivia-se no período imperial, quase como oferecendo uma ilustração tridimensional de um livro.

\begin{tabular}{|l|c|c|}
\hline Do que sentiu falta no Museu Paulista? Tem sugestões? & $f$ & $\%$ \\
\hline Nada + (n)não respondeu & 254 & $52,5 \%$ \\
\hline Monitor/acompanhamento por especialista & 33 & $6,8 \%$ \\
\hline Catálogo/folheto/materiais impressos & 3 & $0,6 \%$ \\
\hline Mais obras/mais objetos/mais salas/exposição maior & 58 & $12,0 \%$ \\
\hline Mais informações/melhor sinalização & 23 & $4,8 \%$ \\
\hline Melhorar infra-estrutura (café/bebedouro/banheiros) & 46 & $9,5 \%$ \\
\hline Outros & 61 & $12,6 \%$ \\
\hline Objetos/peças/obras que estão em exposição & 6 & $1,2 \%$ \\
\hline Total & 484 & $100 \%$ \\
\hline
\end{tabular}

A carência de informações se faz sentir no grande número de visitantes que solicitaram a "oferta de um roteiro guiado" ou o "acompanhamento de alguém especializado na história dos objetos", assim como mais dados sobre o museu.

Mais exposições sobre a história da cidade e informações sobre o tema também aparecem entre as solicitações. Há também sugestões de apresentar textos em inglês e reclamações por não poder tirar fotografias.

Para possibilitar uma visão mais geral das respostas à questão sobre as lacunas do Museu Paulista, apresento a seguir um quadro com as palavras mais citadas pelos visitantes. $\bigcirc$ destaque é para a palavra "mais", pois apesar do Museu Paulista oferecer inúmeras exposições e centenas de objetos para observação, os visitantes parecem insistir em querer ver mais. Em todas as pesquisas que realizei inserindo essa pergunta obtive resultado semelhante. Parece-me que os visitantes acreditam que os museus escondem grandes tesouros em suas reservas técnicas e desejam esgotar todas as possibilidades para não perder nada.

Esse parece um comportamento similar ao do consumidor que deseja conhecer todos os produtos oferecidos, pois pagou sua entrada e pretende fazer uso dela. Seria mais um ponto a ser investigado numa nova pesquisa, a relação dos visitantes dos museus com o mercado cultural e sua visão sobre ele. 


\begin{tabular}{|l|c|}
\hline Palavras citadas cinco ou mais vezes - sentiram falta & $f$ \\
\hline Mais & 42 \\
\hline Guia/instrutor/monitor & 31 \\
\hline História/histórico & 21 \\
\hline Objetos/peças/obras & 19 \\
\hline Banheiro/sanitário & 18 \\
\hline Bebedouro/água & 15 \\
\hline Vestimentas/roupas/trajes & 13 \\
\hline Fotols)/poder tirar fotos & 11 \\
\hline Real/rei & 10 \\
\hline D. Pedro & 8 \\
\hline Lanchonete/bar/restaurante/café & 8 \\
\hline Inglês & 7 \\
\hline Imperador/império & 5 \\
\hline Trono/ióias/coroa & 5 \\
\hline Total & \\
\hline
\end{tabular}

Considerações finais

A partir dos dados aqui analisados, o perfil sociodemográfico dos visitantes de museus de arte, história e ciência estudados tem semelhanças aos dos encontrados em pesquisas fora do Brasil: público de alta renda e bastante escolarizado, especialmente em museu de arte; grupos familiares freqüentam mais museus de ciências e história, enquanto adultos desacompanhados ou acompanhados por outro adulto vão mais a museus de arte; freqüentadores de museus de arte costumam ir mais a museus e teatros do que aqueles que visitam museus de ciências. $\bigcirc$ público do museu de arte parece ser mais especializado, pois costuma visitar mais museus de arte, enquanto nos outros dois museus não há uma clara especialização e/ou preferência. Entretanto percebeu-se também a importância de relativizar os dados das experiências internacionais para poder 
conhecer as especificidades da experiência museal no Brasil e, eventualmente, em determinadas regiões do país.

As motivações parecem ser um pouco diversas em relação aos registros das pesquisas fora do Brasil. Para os visitantes do museu de ciência e museu de história, a motivação principal é trazer/acompanhar familiares ou amigos, enquanto no museu de arte o assunto (a arte) e as exposições temporárias são os maiores atrativos para a visitação. Entretanto novas pesquisas precisam ser executadas para inserir as motivações no universo do mercado cultural e das opções de consumo cultural existentes.

Os benefícios educacionais são os mais citados entre os visitantes do museu de história, enquanto os benefícios culturais são mais citados pelos visitantes do museu de arte. Entretanto, neste último, os benefícios educacionais também são citados com muita freqüência, demonstrando que, em geral, os públicos dos museus pesquisados consideram os museus principalmente um espaço de aprendizagem, mesmo que precisem ser melhor compreendidos os significados de aprendizagem e de cultura para esses visitantes.

público do Museu Paulista é um pouco menos escolarizado, com menor renda e menos freqüentador de museus do que dos outros dois museus, dando-lhe um perfil mais popular. Essa característica talvez esteja mais ligada ao fato de ser um monumento de celebração nacional em um parque do que ser um museu histórico. Essas são hipóteses que precisam ser confirmadas em mais investigações tanto no Museu Paulista como em outros grandes museus históricos brasileiros. Mais um desafio para o conhecimento dos públicos dos museus e de suas leituras sobre essas instituições.

\section{REFERÊNCIAS}

ALMEIDA, A. M.A relação do público com o Museu do Instituto Butantan:análise da exposição 'Na natureza não existem vilões'. 1995. Dissertação (Mestrado), Escola de Comunicações e Artes, Universidade de São Paulo, São Paulo, 1995.

.Avaliações da exposição de longa duração 'Lasar Segall: construção e poética de uma obra'e de sua ação educativa. São Paulo: Museu Lasar Segall, 2001. (Relatório geral).

. Evaluation of the long-term exhibition "Lasar Segall: construction and poetics of an oeuvre”. In: DUFRESNE-TASSÉ, C. (Ed.). L'évaluation, recherché apliquée aux multiples usages/evaluation, applied research with multiple uses/evaluación, pesquisa aplicada con múltiplos usos. Paris: Ceca/Icom, 2002, p. 307-321.

ALMEIDA,A. M.; LOPES, M. M. Modelos de comunicação aplicados aos estudos de públicos de museus. Revista de Ciências Humanas, Taubaté: Unitau, v. 9, n. 2, p. 137-145, jul./dez., 2003.

.Musées d'art, de science et d'histoire au Brésil: quels sont leurs visiteurs? In :DUFRESNETASSÉ (Ed.). Familles, adultes et personnes âgées au musées, recherches et perspectives/Families, 
adults and old age visitors in museums, research and perspectives/Familias, adultos y jubilados en el museo, investigacion y perspectivas. Paris: Conseil Internacional des Musées (no prelo).

BOURDIEU, P.; DARBEL, A. O amor pela arte: os museus de arte na Europa e seu público. Tradução por Guilherme João de Freitas Teixeira. São Paulo: Edusp/Zouk, 2003 (Traduzido da edição francesa de 1969).

BREFE, A. C. História nacional em São Paulo: o Museu Paulista em 1922. Anais do Museu Paulista. São Paulo, v. 10/11, p. 79-103, 2003.

CAMERON, D. F. The pilgrim and the shrine: the icon and the oracle: a perspective on museology tomorrow. Museum management and curatorship. v. 14, n. 1, p. 47-55, 1995.

CIMET, E.; DUJOVNE, M.; CANCLINI, N. G.; GULlCO, J.; MENDONZA, C.; PALMA, F. R.; SOLTERO, G. El público como propuesta: cuatro estudios sociológicos en museos de arte. México: Inba, 1987.

CLARK, M.; BARTOLOMEO. A study of visitors to the Metropolitan Museum of Art. New York: Metropolitan Museum of Art, 1985.

DENNERT, D. Open for new learning. Museum facing economic and social changes. In: KEYNOTE SPEECH, CECA/ICOM INTERNATIONAL CONFERENCE, Barcelona, 2001.

DIGBY, P.W. Visitors to three London Museums: a survey of visitors to the British Museum, Science Museum and National Maritime Museum, London: Office of Population Censuses and Surveys, 1973.

DOERING, Z. Who attends our cultural institutions? A progress report. Washington: Smithsonian Institution, 1995.

DOERING, Z.; BICKFORD, A. Visitors to the Smithsonian Institution: A summary of studies, Washington: Smithsonian Institution: Institutional Studies Office, 1997.

FALK, J.; DIERKING, L. The museum experience. Washington:Whalesback Books, 1992.

. Learning from museums: visitor experiences and the making of meaning. Boston, Maryland: Altamira Press, 2000.

FREIRE, C. Museu. Público.Arte Contemporânea. Um triângulo nem sempre amoroso.ARTEunesp, São Paulo, n. 9,p. 131-146, 1993.

HEIZER, A. Uma casa exemplar: pedagogia, memória e identidade no Museu Imperial de Petrópolis. 92 f. Dissertação (Mestrado em Educação) - Departamento de Educação, Pontifícia Universidade Católica do Rio de Janeiro, Rio de Janeiro, 1994,

HOOD, M. G. Staying away: why people choose not to visit museums. Museum News, v. 6, n. 4, p. $50-57$, apr., 1983 .

LEHALLE, E.; MIRONER, L. Musées et visiteurs: un observatoire permanent des publics, Paris: Dirección des musées de France, 1993. 
LINTON, J.;YOUNG, G.; ERNST AND YOUNG;THEAUDIENCE RESEARCH CONSORTIUM.A survey of visitors at an art gallery, cultural history museum, science center, and zoo. ILVS Review, v. 2, n. 2, p. 239-259, 1992.

MENESES, U. B. Pintura Histórica: documento histórico? In: .et al. Como explorar um museu bistórico. São Paulo: Museu Paulista/USP, p. 22-25, 1992a.

.Museus históricos: da celebração à consciência histórica. In: .et al. Como explorar um museu bistórico. São Paulo: Museu Paulista/USP, p.7-10, 1992 b.

.O salão nobre do Museu Paulista e o teatro da História. In: .et al. Como explorar um museu bistórico. São Paulo: Museu Paulista/USP, p. 25-29, 1992c.

Do teatro da memória ao laboratório da história: a exposição museológica e o conhecimento histórico. Anais do Museu Paulista. São Paulo: [n.s.], v. 2, p. 9-42, jan./dez1994a.

.O Museu Paulista. Estudos Avançados, n. 22, p. 573-8, 1994b.

MERRIMAN, N.The social basis of museum and heritage visiting. In: Pearce, S. (Ed.). Museum studies in material culture. London: Leiscester University Press, 1989, p. 153-171.

OBSERVATOIRE PERMANENT DES PUBLICS. Les visiteurs du Louvre. Paris: Musée du Louvre, 1999.

.Le public du Musée du Louvre em 1999. Synthèse. Paris: Musée du Louvre, 2000.

OLIVEIRA, C. H. S. O Museu Paulista da USP e a memória da Independência. Caderno Cedes, Campinas, v. 22, n. 58, p. 65-80, 2002.

. Museu Paulista: espaço de avocação do passado e reflexão sobre a história. Anais do Museu Paulista. São Paulo, v. 10/11, p. 105-126, 2003.

PAULA,T.T.D. Tecidos no Brasil:um hiato. 2004. 229 f.Tese (Doutorado) - Escola de Comunicações e Artes, Universidade de São Paulo, São Paulo, 2004.

PINACOTECA DO ESTADO. Você e o museu: pesquisa de perfil do público espontâneo da Pinacoteca do Estado. São Paulo: Pinacoteca do Estado, Área de Ação Educativa, 2002.

PRENTICE, R.; DAVIES, A; BEEHO, A. Seeking generic motivations for visiting and not visiting museums and like cultural attractions. Museum management and curatorship, v.16, n. 1, p. 45$70,1997$.

ROCHA,A. L. G.; MOUTINHO, C. S. Análise estatística dos visitantes do Museu da República. Rio de Janeiro: Escola Nacional de Ciências Estatísticas, 1997.

RUFFINS, F. D. Interpreting the past in the present. Journal of the Washington Academy of Sciences, v. 76, n. 2, p. 25-130, jun., 1986. 
SANTOS, M. C. L. (Org.). Universidade de São Paulo: alma mater paulista - 63 anos. São Paulo: Edusp/Imprensa Oficial, 1998.

SCHÄFER, H.; DENNERT, D.; VON WERSEBE, H. Learning history in museums. In: THE 20th CENTURY, AN INTERPLAY OF VIEWS, Council of Europe, Museum of Contemporary History in Germany, 2001. (Conference).

SCHUSTER, J. M. D. The audience of American art museums. National Endowment for the arts, Research Division Report, n. 23, second print, 1992.

SECRETARIA MUNICIPAL DE CULTURA;VOX MERCADO. Primeiro diagnósticos da área cultural de Belo Horizonte. Belo Horizonte: Secretaria Municipal de Cultura, 1996.

SICARD, M. Ce que fait le musée... Science et art, les chemins du regard.Publics E Musées, n. 16, p. 41-53, 2001.

SILVA, C. S. Pesquisa de público em museus e instituições abertas à visitação: fundamentos e metodologias. Dissertação (Mestrado em Comunicações) - Escola de Comunicação, Universidade Federal do Rio de Janeiro, Rio de Janeiro, 1989.

STUDART, D.; ALMEIDA,A. M.;VALENTE, M.E.A. Pesquisa de público em museus: desenvolvimento e perspectivas. In: GOUVÊA, G.; MARANDINO, M; LEAL, M.C. (Org.). Educação e museu: $a$ construção social do caráter educativo dos museus de ciência. Rio de Janeiro: Faperj/Access, 2003, p. 129-157.

Artigo apresentado em 08/2004. Aprovado em 10/2004. 